\title{
Article \\ Optimization of Composition and Technological Factors for the Lightweight Fiber-Reinforced Concrete Production on a Combined Aggregate with an Increased Coefficient of Structural Quality
}

\author{
Levon R. Mailyan ${ }^{1}$, Alexey N. Beskopylny ${ }^{2, * \mathbb{D}}$, Besarion Meskhi ${ }^{3}$, Sergey A. Stel'makh ${ }^{4}$, \\ Evgenii M. Shcherban ${ }^{4}$ (D) and Oxana Ananova 5
}

check for updates

Citation: Mailyan, L.R.; Beskopylny, A.N.; Meskhi, B.; Stel'makh, S.A.; Shcherban, E.M.; Ananova, O. Optimization of Composition and Technological Factors for the Lightweight Fiber-Reinforced Concrete Production on a Combined Aggregate with an Increased Coefficient of Structural Quality. Appl. Sci. 2021, 11, 7284. https://doi.org/ 10.3390/app11167284

Academic Editors: Dario De Domenico and Giuseppe Lacidogna

Received: 3 July 2021

Accepted: 6 August 2021

Published: 8 August 2021

Publisher's Note: MDPI stays neutral with regard to jurisdictional claims in published maps and institutional affiliations.

Copyright: (C) 2021 by the authors. Licensee MDPI, Basel, Switzerland. This article is an open access article distributed under the terms and conditions of the Creative Commons Attribution (CC BY) license (https:// creativecommons.org/licenses/by/ $4.0 /)$.
1 Department of Roads, Don State Technical University, 344000 Rostov-on-Don, Russia; Irm@aaanet.ru

2 Department of Transport Systems, Faculty of Roads and Transport Systems, Don State Technical University, 344000 Rostov-on-Don, Russia

3 Department of Life Safety and Environmental Protection, Faculty of Life Safety and Environmental Engineering, Don State Technical University, 344000 Rostov-on-Don, Russia; reception@donstu.ru

4 Department of Engineering Geology, Bases, and Foundations, Don State Technical University, 344000 Rostov-on-Don, Russia; sergej.stelmax@mail.ru (S.A.S.); au-geen@mail.ru (E.M.S.)

5 Department of Marketing and Engineering Economics, Faculty of Innovative Business and Management, Don State Technical University, 344000 Rostov-on-Don, Russia; o_ananova@mail.ru

* Correspondence: besk-an@yandex.ru; Tel.: +7-863-273-8454

\begin{abstract}
In recent years, developing lightweight concrete with both the necessary and sufficient strength characteristics is essential in the construction industry. This article studies the influence of the volumetric composition of lightweight fiber-reinforced concrete (LFRC) and the method of its distribution during the preparation of the fiber-concrete mixture on the strength and deformation characteristics of LFRC on a combined aggregate. The optimal grain size of the porous filler was calculated by the mathematical planning method of the experiment. Regression models of the strength and deformation characteristics on the volumetric content of fiber and its distribution method were obtained. The most effective combination of these factors has been determined. The model shows that the increase in compressive strength was $12 \%$, the value of the prismatic strength increased by $25 \%$, the bending tensile strength increased by $34 \%$, and the axial tensile strength increased by $11 \%$. The ultimate strains during axial compression decreased by $10 \%$, axial tension decreased by $12 \%$, and the elasticity modulus increased by $11 \%$ compared to the test results of the control composition samples without fiber and pumice. The coefficient of constructive quality (CCQ) of the LFRC on a combined aggregate compared to concrete with the control composition without fiber and pumice showed an increase of more than $32 \%$. It was also found that fiber reinforcement with basalt fibers with a combination of heavy and porous aggregates achieves a synergistic effect together.
\end{abstract}

Keywords: fiber reinforced concrete; hybrid reinforcement; compressive strength; tensile strength; ultimate deformations; optimal composition

\section{Introduction}

\subsection{The Relevance of Research}

The urgency in the problem of the developing lightweight concrete is due to the increasing need for innovative building materials that also have sufficient strength characteristics and significantly lower mass.

High density urban planning and a variety of engineering and geological conditions lead to the need to construct buildings and structures with reduced weight. With an increase in the number of stories and the construction of new large-span and high-rise buildings 
with high requirements for the strength and deformability of the building materials, an urgent problem arises regarding the sufficiently durable and at the same time lightweight new generation products [1]. The development of new materials with high strength and low weight is an important scientific problem.

Fiber-reinforced concrete has proven its effectiveness in the construction of basement panels for multi-story buildings [1], fixed formwork to strengthen pile foundations, wall panels and monolithic walls, small architectural forms for the urban beautification architectural decoration of buildings, and many others. However, despite the demand, the scientific problem of the development and application of LFRC remains unresolved and attracts the attention of scientists around the world [1,2].

\subsection{Review and Analysis of Literary Sources}

One of the technological ways of improving fine-grained lightweight concrete properties is dispersed reinforcement. The work conducted in [3] investigates the strength properties of fine-grained concrete reinforced with amorphous fiber based on the Fe-BC system and obtained by the "spinning" method. These are concrete types reinforced with available sorts of fiber that are based on mineral wool, basalt fiber, glass fiber, steel, and polypropylene fibers. The best tensile bending strength was shown by samples with amorphous fiber, and the highest compressive strength was shown in samples with steel fiber. The inclusion of amorphous fibers increases flexural strength by $56 \%$ but decreases compressive strength by $30 \%$ compared to the control samples. The addition of steel fiber shows a $20 \%$ increase in flexural strength and a $14 \%$ increase in compressive strength, confirming the beneficial effect of adding commercially available fiber to fine concrete. The authors developed compositions of fiber-reinforced concrete with a compressive strength of up to $38 \mathrm{MPa}$ and a bending strength of up to $12 \mathrm{MPa}$, making it possible to use amorphous fiber as a composition of fine-grained concrete in construction.

The mechanical properties and durability of lightweight concrete based on pumice stone reinforced with basalt fiber and containing nano ground calcium carbonate (GCC) was studied in [4]. Pumice stone is the most promising substitute for heavy aggregate due to its availability, cheapness, and reasonable mechanical characteristics. GCC was used as a replacement for Portland cement in different percentages from 5 to $25 \%$ in $5 \%$ increments. Basalt fibers $6 \mathrm{~mm}$ in length were added in two amounts: $0.5 \%$ and $1 \%$ by volume. Research results showed that mixes with added GCC had lower mechanical strength at an early age and were comparable to control specimens at a later age. The addition of GCC also decreased water absorption, sorption capacity, and increased resistance to magnesium sulfate compared to a lightweight concrete control. The use of basalt fiber improved the mechanical properties of lightweight concrete based on pumice but worsened the properties of freshly prepared concrete. It was shown that the resulting type of concrete could be used in the industry to produce environmentally friendly concrete blocks along with geopolymer lightweight concrete $[5,6]$.

In [7], the influence of chopped basalt fiber in expanded clay concrete to improve its strength was tested. Experimental dependencies of the concrete behavior under load were obtained using compression and bending tests. Finite element analysis was performed using ANSYS software. The model was developed to test various experimental results that showed that a high percentage of basalt fiber in expanded clay concrete increases its strength. In fact, the direct effect on the nature of destruction was observed on expanded clay concrete without basalt fiber and was then read according to the value of strength and the ultimate deformation of the samples.

Numerical modeling is an effective tool in studying fiber-reinforced concrete with complex properties [8,9]. In article [10], the authors used the ANSYS numerical modeling method to simulate the design parameters of beams, which can be changed depending on the bearing capacity, such as:

- The content of steel fiber in the concrete;

- The distance between steel clamps at the ends of the beam; 
- The number of tensile steel rods;

- The diameter of the stretched steel bars,

- Taking into account the nonlinear properties of the materials.

In [11], a study on the inclusion of nanosilica in ultra-lightweight foam concrete (ULFC) was conducted considering the effectiveness of various dosages up to $10 \mathrm{wt} . \%$. The results of the experiments showed that the use of nanosilica in the optimal dosage is an effective way to increase the stability of foam bubbles in the fresh state, to reduce the anisotropy of the pores, and to make it possible to produce foam concrete with an increased wall thickness.

The possibility of using a mixture of cement, fly ash, ground granulated blast-furnace slag, and river sand to produce pre-foamed ultralight composite material (PULC) was investigated in [12]. It was shown that replacing $20 \%$ cement with slag resulted in the highest compressive strength as well as the lowest the water absorption value of the PULC samples. The thermal conductivity properties were also numerically investigated, which were inversely proportional to the density of the PULC samples and showed good performance.

Artificial neural networks are actively used to predict the mechanical properties of fiber-reinforced concrete [13-18]. In [19], using artificial neural networks, an analytical model was obtained that describes the final bond strength in terms of the average values of the shear stress. The object of research was concrete of various strength classes that had been reinforced with metal and composite reinforcement. It has been established that the adhesion value is related to the strength characteristics of the concrete and the type of reinforcement used. An artificial neural network technique was proposed in [20] to predict the bond strength of the fiber and cement matrix.

The assessment of the ultimate values of strength and deformability for ultra-high quality fiber reinforced concrete (UHPFRC) elements was conducted in [21-23]. In these studies, an experimental program was implemented on UHPFRC elements by taking into account the influence of the fiber volume fraction, the ratio of shear length to depth, and the compressive strength of the matrix as the main variables. It was shown that the inclusion of steel fiber with a volume fraction of $2 \%$ significantly increases the shear and flexural strength of ultra-high foam rubber beams.

\subsection{The Objective of the Research}

The main aim of the research presented in this article was to develop a dispersedreinforced lightweight concrete [24-28] that includes both heavy and light aggregate [29]. Thus, a part of the traditional heavy aggregate from dense rocks was replaced by an analogue of lightweight porous filler with equal volume but that was significantly lighter in weight. Granite crushed stone and slag pumice were used as initial components. As a result of the study, a technical problem regarding the reduction of building weight was solved due to the decrease in the density of the concrete while maintaining its strength. Additionally, the problem of reducing building and structure costs was considered since as a result of our recommendations, the proposed concrete significantly decreases the building and structure cost due to the lower cost of slag pumice compared to granite.

Additionally, the aim of this work is to identify and develop proposals for a rational formulation and technology for new materials with an increased coefficient of constructive quality (CCQ). In the scientific and technical literature, CCQ means the ratio of the strength and density characteristics [24-28].

\section{Materials}

During the experimental research, grade PC 500 D0 Portland cement produced by Oskolcement OJSC was used. Table 1 shows some of the physical and mechanical characteristics of the Portland cement that was used, such as the fineness, the normal consistency, the setting time of the cement paste, and the ultimate bending and compression strength at the ages of 7 and 28 days. Table 2 shows the chemical and mineralogical composition of Portland cement. 
Table 1. Physical and mechanical characteristics of Portland cement.

\begin{tabular}{|c|c|c|c|c|c|c|c|}
\hline $\begin{array}{c}\text { Portland } \\
\text { Cement PC } 500 \\
\text { Do Produced by } \\
\text { Oskolcement } \\
\text { OJSC }\end{array}$ & $\begin{array}{c}\text { Grinding } \\
\text { Fineness, by } \\
\text { Specific Surface, } \\
\mathrm{cm}^{2} / \mathrm{g}\end{array}$ & $\begin{array}{c}\text { Normal } \\
\text { Consistency of } \\
\text { Cement Paste, } \%\end{array}$ & $\begin{array}{c}\text { Setting Time of } \\
\text { Cement Paste, } \\
\text { min. }\end{array}$ & $\begin{array}{c}\text { Bending } \\
\text { Strength, MPa } \\
\text { (at the Age of } \\
7 \text { Days) }\end{array}$ & $\begin{array}{c}\text { Compressive } \\
\text { Strength, MPa } \\
\text { (at the Age of } \\
7 \text { Days) }\end{array}$ & $\begin{array}{c}\text { Bending } \\
\text { Strength, MPa } \\
\text { (at the Age of } \\
28 \text { Days) }\end{array}$ & $\begin{array}{c}\text { Compressive } \\
\text { Strength, MPa } \\
\text { (at the Age of } \\
28 \text { Days) }\end{array}$ \\
\hline $\begin{array}{c}\text { Research } \\
\text { methodology }\end{array}$ & GOST 310.2 & GOST 310.3 & GOST 30744 & GOST 30744 & GOST 30744 & GOST 30744 & GOST 30744 \\
\hline Research result & 2964.2 & 28.6 & $\begin{array}{l}\text { Start-145 } \\
\text { finish-240 }\end{array}$ & 6.0 & 26.8 & 8.1 & 52.4 \\
\hline
\end{tabular}

Table 2. Mineralogical and chemical composition of Portland cement.

\begin{tabular}{|c|c|c|c|c|c|c|c|c|c|c|c|c|}
\hline \multirow{2}{*}{$\begin{array}{l}\text { Cement } \\
\text { Grade }\end{array}$} & \multicolumn{4}{|c|}{ Mineralogical Composition, $\%$} & \multicolumn{8}{|c|}{ Chemical Composition, $\%$} \\
\hline & $\mathrm{C}_{3} \mathrm{~S}$ & $\mathrm{C}_{2} \mathrm{~S}$ & $\mathrm{C}_{3} \mathrm{~A}$ & $\mathrm{C}_{4} \mathrm{AF}$ & $\mathrm{MgO}$ & $\mathrm{SO}_{3}$ & $\mathrm{Al}_{2} \mathrm{O}_{3}$ & $\mathrm{Fe}_{2} \mathrm{O}_{3}$ & $\mathrm{Na}_{2} \mathrm{O}+\mathrm{K}_{2} \mathrm{O}$ & $\mathrm{CaO}$ & $\mathrm{SiO}_{2}$ & Impurity \\
\hline $\begin{array}{c}\text { PC } 500 \\
\text { D0 }\end{array}$ & 68.9 & 10.9 & 8.9 & 11.3 & 0.9 & 2.3 & 4.6 & 3.8 & 0.7 & 60.1 & 24.0 & 3.6 \\
\hline
\end{tabular}

Crushed granite was used as a large aggregate, and slag pumice was used as a combined aggregate (Figure 1a,b).

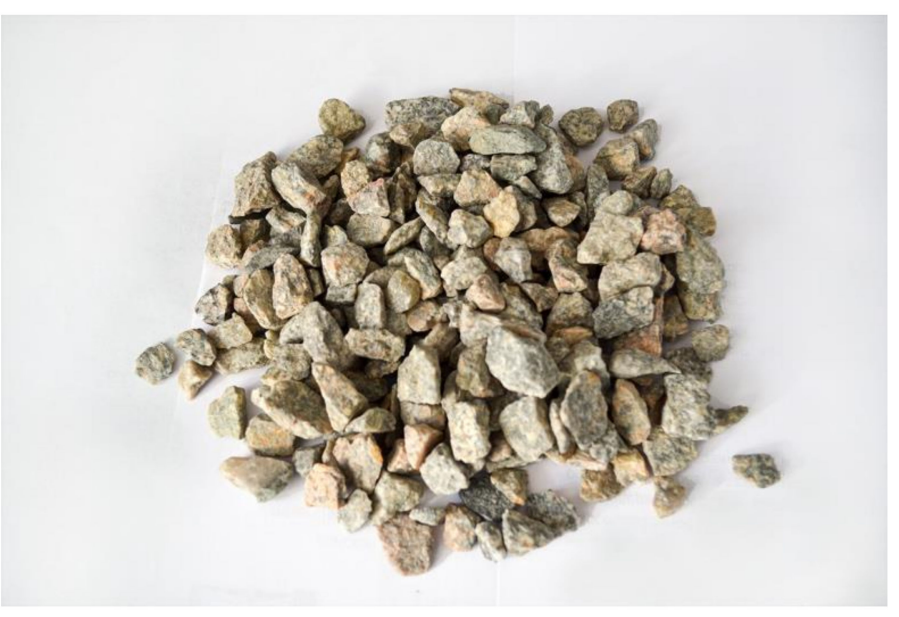

(a)

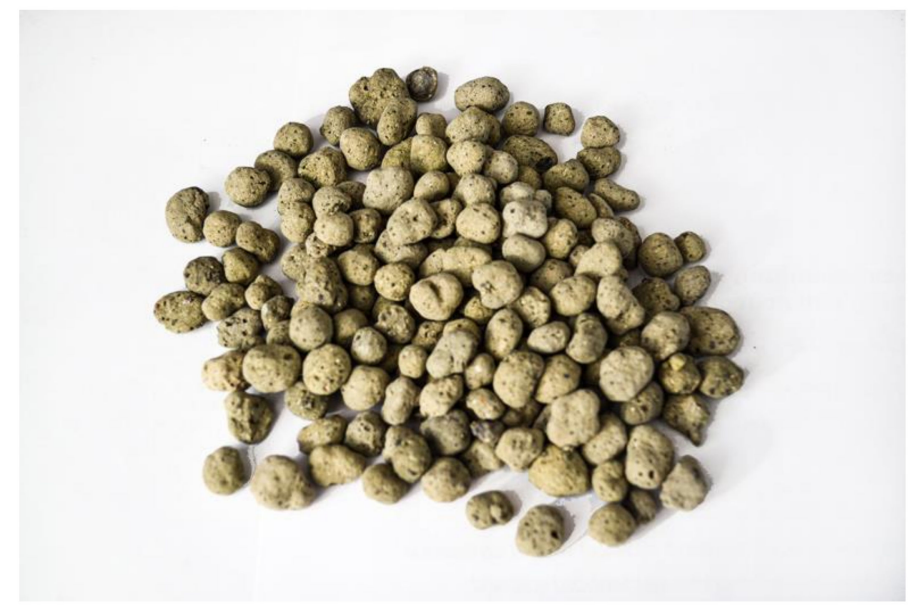

(b)

Figure 1. Crushed granite (a) used as a large aggregate and slag pumice (b) used as a combined aggregate.

The physical and mechanical characteristics of which are presented in Table 3.

Table 3. Physical and mechanical characteristics of crushed stone.

\begin{tabular}{ccccccc}
\hline Fraction & Density, $\mathbf{g} / \mathrm{cm}^{3}$ & $\begin{array}{c}\text { Bulk Density, } \\
\mathbf{k g} / \mathbf{m}^{3}\end{array}$ & Porosity, \% & $\begin{array}{c}\text { Content of Dust } \\
\text { and Clay } \\
\text { Particles, wt. \% }\end{array}$ & $\begin{array}{c}\text { Content of Lamellar and } \\
\text { Needle-Shaped Grains, } \\
\text { wt. \% }\end{array}$ & Crushing, wt. \% \\
\hline $5-20$ & 2.85 & 1470 & 45.7 & 0.65 & 23 & 12.7 \\
\hline
\end{tabular}

Quartz sand was used as a fine aggregate, the physical and mechanical characteristics of which are presented in Table 4.

Table 4. Physical properties of fine aggregate.

\begin{tabular}{ccccc}
\hline Density, $\mathbf{g} / \mathbf{c m}^{\mathbf{3}}$ & $\begin{array}{c}\text { Bulk Density, } \\
\mathbf{k g} / \mathbf{m}^{\mathbf{3}}\end{array}$ & Size Module & Porosity, \% & $\begin{array}{c}\text { Water } \\
\text { Demand, \% }\end{array}$ \\
\hline 2.62 & 1480 & 1.4 & 43.3 & 9 \\
\hline
\end{tabular}


Table 5 shows the grain densities for the combined mixtures. The mineralogical composition of slag pumice is characterized by:

- $\quad$ Light minerals $(80 \%)$, which include calcium and magnesium carbonates $(68 \%)$ and quartz $(12 \%)$;

- Heavy minerals (18\%), represented by onormanite in the form of short square prisms;

- Ferrous sulfate $(2 \%)$.

Table 5. Density limits of grains for combined mixtures.

\begin{tabular}{|c|c|c|c|}
\hline \multirow{4}{*}{$\begin{array}{l}\text { Average Bulk Density of } \\
\text { Grains, } \mathrm{kg} / \mathrm{m}^{3}\end{array}$} & \multicolumn{3}{|c|}{ Slag Pumice } \\
\hline & \multicolumn{3}{|c|}{ Aggregate Fractions, mm } \\
\hline & $5-10$ & $2.5-5$ & $1.25-2.5$ \\
\hline & $(1.4-1.5) \times 10^{3}$ & $(1.5-1.8) \times 10^{3}$ & $(1.6-1.8) \times 10^{3}$ \\
\hline
\end{tabular}

Basalt fiber was used as a dispersed reinforcement. Table 6 shows the physical and mechanical characteristics of the used fiber.

Table 6. Physical and mechanical properties of the fiber.

\begin{tabular}{|c|c|c|c|c|c|c|}
\hline \multirow{2}{*}{ Basalt Fiber } & $\begin{array}{c}\text { Tensile } \\
\text { Strength, MPa }\end{array}$ & $\begin{array}{l}\text { Fiber Diameter, } \\
\text { mm }\end{array}$ & $\begin{array}{c}\text { Fiber Length, } \\
\text { mm }\end{array}$ & $\begin{array}{c}\text { Elastic } \\
\text { Modulus, GPa }\end{array}$ & Density, $\mathrm{g} / \mathrm{cm}^{3}$ & $\begin{array}{c}\text { Elongation } \\
\text { Coefficient, } \%\end{array}$ \\
\hline & 3200 & $16 \times 10^{-3}$ & 12 & 120 & 2.6 & 3.2 \\
\hline
\end{tabular}

To regulate the concrete consistency, the superplasticizer Muraplast FK 48 was used (density-1.18-1.21 g/ $\mathrm{cm}^{3}$, dosage- $0.2-2.0 \%$ by weight of cement). It is a highly concentrated, modified condensation product of naphthalene formaldehyde sulfonic acid, does not contain components that cause reinforcement corrosion, effectively disperses the cement paste in the concrete mixture, strongly plasticizes the concrete mixture and reduces its water demand, and reduces the cost of laying and compacting concrete. The recommended consumption of the additive is $1.5 \%$ of the cement mass.

\section{Methods}

The following test equipment was used for this research: a laboratory concrete mixer; a laboratory vibrating platform (type SMZH-539-220A, OOO I-MACH, Armavir, Russia); a hydraulic test press (type IP-1000, Neftekamsk, OOO NPK “TEKHMASH", Russia) designed for static compression tests of the concrete samples; a universal tensile testing machine (type R-50, OOO I-MACH, Armavir, Russia) for the axial tension testing of the prisms [26,27].

Measurements of the concrete deformations of the test prisms were conducted with a chain of strain gauges with a side length of $50 \mathrm{~mm}$ and dial indicators with a graduation of $0.001 \mathrm{~mm}$.

Experimental prisms were tested for axial compression and axial tension at a constant rate of deformation to obtain not only the strength and deformation characteristics of concrete, but to also obtain its full deformation diagrams " $\sigma-\varepsilon$ " with a descending curve.

Compression and tensile bending tests were conducted in accordance with the requirements of GOST 10180 “Concretes. Methods for strength determination using reference specimens" [30].

The axial compression and axial tension tests were conducted in accordance with the requirements of GOST 24452 "Concretes. Methods of prismatic, compressive strength, modulus of elasticity and Poisson's ratio determination" [31].

The experimental research program is shown in Figure 2. 


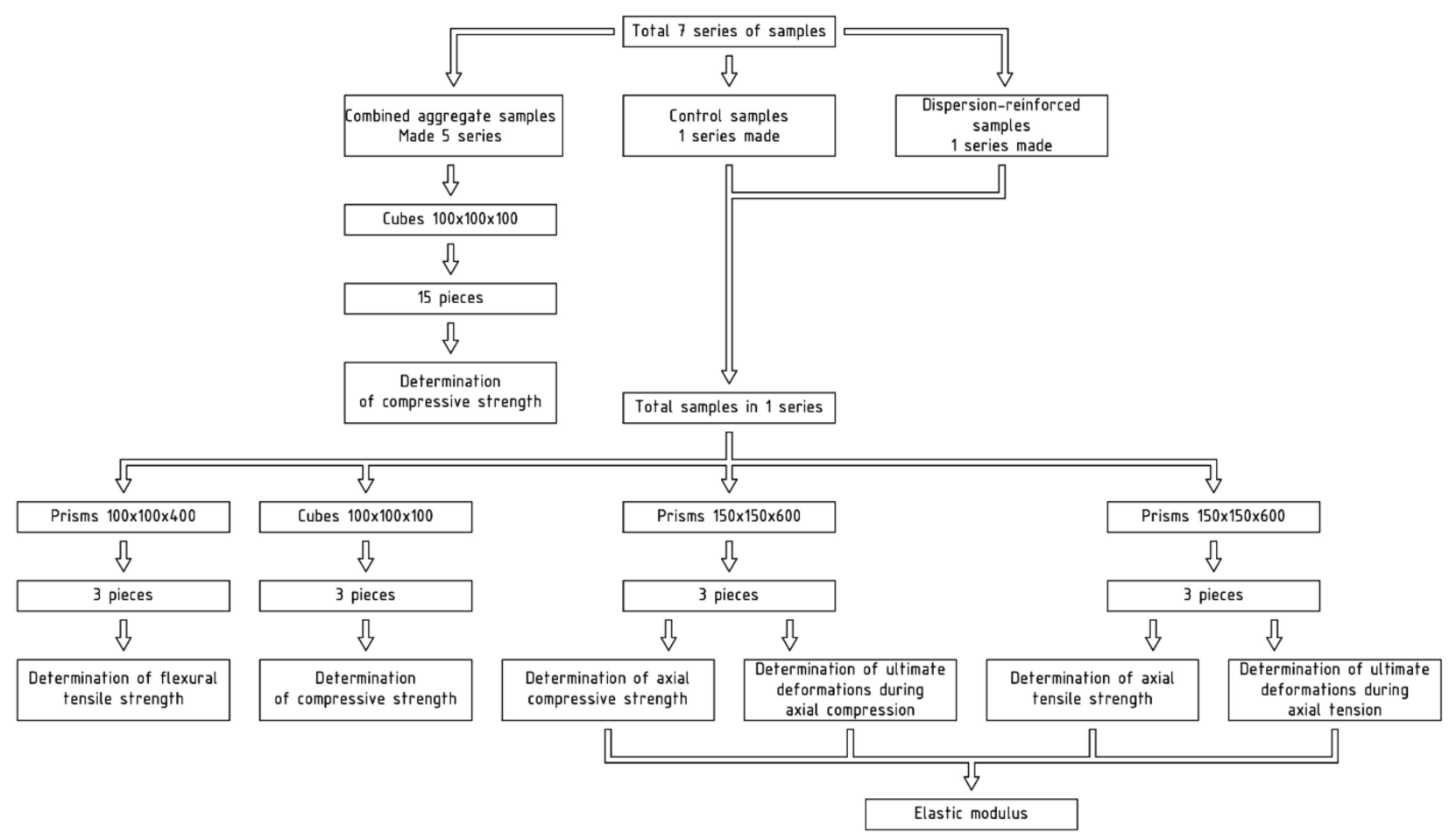

Figure 2. Block diagram of the experiment program.

A series is a set of samples made from the same composition. The prism sizes in Figure 1 are in $\mathrm{mm}$.

The process of determining the deformation of a prism sample under axial compression is shown in Figure 3a,b.

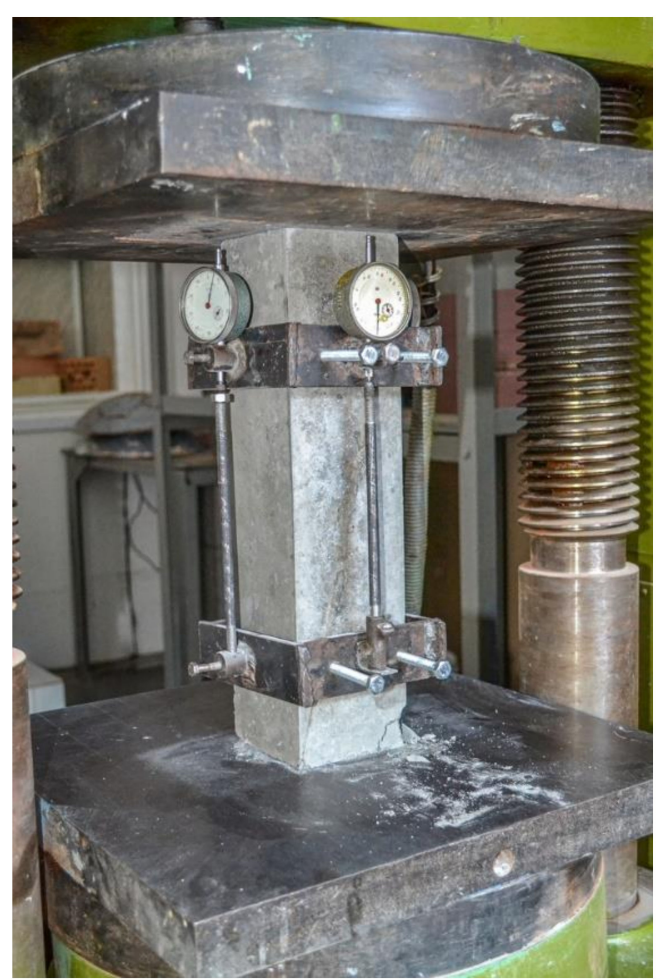

(a)

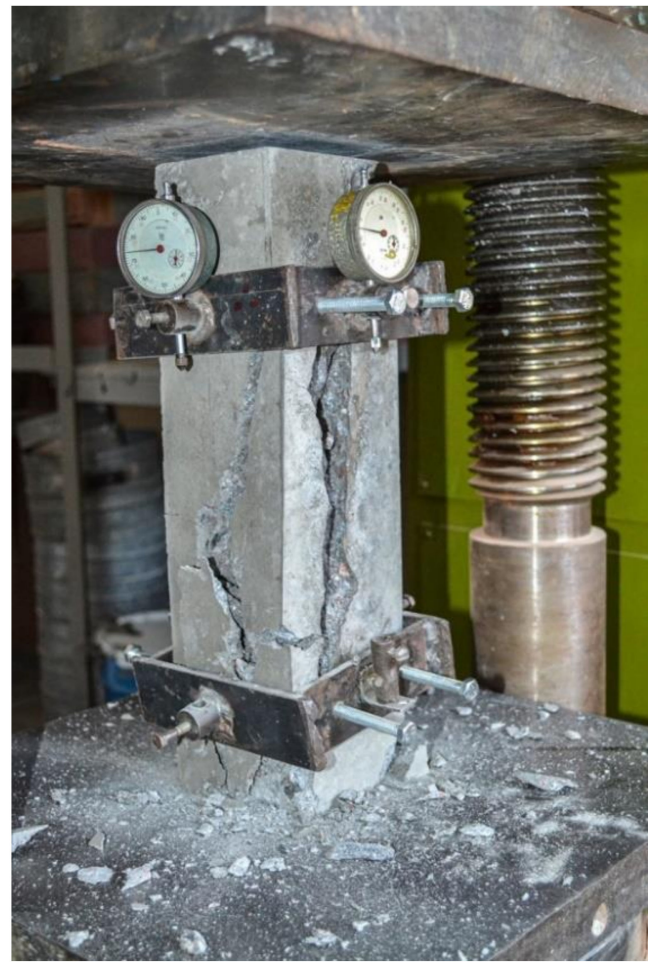

(b)

Figure 3. Photo of determining the deformation of the prism sample under axial compression (a); destroyed sample (b). 
Using the method of absolute volumes [32], the initial composition of the concrete mixture was determined:

- Water-cement ratio:

$$
\frac{W}{C}=\frac{A R_{C}}{\left(R_{b}+0.5 A R_{S}\right)}
$$

where $A$ is the coefficient depending on the quality of the materials; $R_{C}$ is the activity of the Portland cement; $R_{b}$ is the concrete strength.

$W$ is the water consumption considering the required mobility determined from the graphs and was $W=205 \mathrm{~L} / \mathrm{m}^{3}$.

- Portland cement consumption, $\mathrm{kg} / \mathrm{m}^{3}$ :

$$
S=\frac{W}{W / C}
$$

- the crushed stone consumption, $\mathrm{kg} / \mathrm{m}^{3}$ :

$$
C S=\frac{1000}{\alpha \frac{P_{C S}}{\rho_{t}^{C S}}+\frac{1}{\rho_{b}^{C S}}}
$$

where $\alpha$ is the coefficient of grain spreading; $P_{C S}$ is the porosity; $\rho_{t}^{C S}$ is the true density of the crushed stone; $\rho_{b}^{C S}$ is the bulk density of the crushed stone.

- sand consumption, $\mathrm{kg} / \mathrm{m}^{3}$ :

$$
S=\rho_{t}^{S}\left(1000-\frac{C}{\rho_{t}^{C}}-\frac{C S}{\rho_{t}^{C S}}-W\right)
$$

where $\rho_{t}^{S}$ is the true density of the sand; $\rho_{t}^{C}$ is the true density of the Portland cement; $C, C S$, and $W$ are the consumption of the Portland cement, crushed stone, and water, respectively. - the estimated density of the concrete mixture in a compacted state, $\mathrm{kg} / \mathrm{m}^{3}$ :

$$
\rho_{C M}=C+C S+S+W
$$

The parameters of the composition of the concrete mixture obtained as a result of the calculations are reflected in Table 7.

Table 7. Parameters of the composition of the concrete mixture.

\begin{tabular}{ccccccc}
\hline $\begin{array}{c}\text { Parameter } \\
\text { Name }\end{array}$ & $\frac{W}{C}$ & $C, \mathbf{k g} / \mathbf{m}^{3}$ & $W, \mathbf{L} / \mathbf{m}^{3}$ & $C S, \mathbf{k g} / \mathbf{m}^{\mathbf{3}}$ & $S, \mathbf{k g} / \mathbf{m}^{\mathbf{3}}$ & $\begin{array}{c}\rho_{\text {cm }} \\
\mathbf{~ k g} / \mathbf{m}^{\mathbf{3}}\end{array}$ \\
\hline Value & 0.55 & 373 & 205 & 1139 & 720 & 2437 \\
\hline
\end{tabular}

The cube compressive strength of the control composition on a dense aggregate was $R_{\text {b.cub }}=65.2 \mathrm{MPa}$.

\section{Results}

The determination of the optimal grain size composition of the porous filler was conducted using the mathematical planning method of the full-factor experiment (FFE 2k) using the program "MathCAD". The plans were used when the first-order planning did not allow an adequate regression model to be obtained, and the need for its complication became clear. Additionally, it may be used if it is known that the research object has significant nonlinear properties in advance. Compared to plans of the first order, plans of the second order are more complex in structure, have a larger number of points and levels of variation for each factor, and require an increased number of experiments in their implementation.

The parameters were taken as the response function: 
- $\quad \rho_{b}$-bulk density of the slag pumice mixture, $\mathrm{kg} / \mathrm{m}^{3}$;

- $\rho_{b v}$-bulk density of vibro-compacted slag pumice, $\mathrm{kg} / \mathrm{m}^{3}$ (vibration compaction time $1.5 \mathrm{~min}$ );

- $\quad V_{s p}$-the voidness of the slag pumice mixture, $\%$.

The results of experimental studies are presented in Table 8.

Table 8. Results of the slag pumice experimental studies.

\begin{tabular}{|c|c|c|c|c|c|c|}
\hline \multirow{3}{*}{ No. } & \multicolumn{3}{|c|}{ Slag Pumice Fraction Size, $\mathrm{mm}$} & \multirow{3}{*}{$\begin{array}{l}\text { Bulk Density } \\
\text { of Slag Pumice } \\
\text { Mixture, kg/m }{ }^{3}\end{array}$} & \multirow{3}{*}{$\begin{array}{c}\text { Bulk Density of } \\
\text { Vibro-Compacted } \\
\text { Slag Pumice, kg/m } 3\end{array}$} & \multirow{3}{*}{$\begin{array}{c}\text { Voidness of } \\
\text { Slag Pumice } \\
\text { Mixture, } \%\end{array}$} \\
\hline & $5-10\left(x_{1}\right)$ & $2.5-5\left(x_{2}\right)$ & $1.25-2.5\left(x_{3}\right)$ & & & \\
\hline & \multicolumn{3}{|c|}{ Volume Content of This Fraction, \% } & & & \\
\hline 1 & 1 & 0 & 0 & 968 & 1088 & 37.8 \\
\hline 2 & 0 & 1 & 0 & 1003 & 1130 & 32.3 \\
\hline 3 & 0 & 0 & 1 & 1038 & 1155 & 27.0 \\
\hline 4 & $1 / 2$ & $1 / 2$ & 0 & 1023 & 1110 & 37.0 \\
\hline 5 & $1 / 2$ & 0 & $1 / 2$ & 1115 & 1272 & 14.5 \\
\hline 6 & 0 & $1 / 2$ & $1 / 2$ & 1095 & 1198 & 28.0 \\
\hline 7 & $1 / 3$ & $1 / 3$ & $1 / 3$ & 1096 & 1205 & 26.1 \\
\hline 8 & $3 / 5$ & $1 / 5$ & $1 / 5$ & 1076 & 1196 & 29.4 \\
\hline 9 & $1 / 5$ & $3 / 5$ & $1 / 5$ & 1076 & 1186 & 31.0 \\
\hline
\end{tabular}

As a result of statistic processing of the experimental data, a mathematical model was obtained for the bulk density of the mixture of aggregates in its natural state:

$$
\rho_{b}=968 x_{1}+1003 x_{2}+1038 x_{3}+150 x_{1} x_{2}+448 x_{1} x_{3}+298 x_{2} x_{3}
$$

In the case of a vibrationally compacted mixture of grains, the equation takes the form:

$$
\rho_{b v}=1088 x_{1}+1130 x_{2}+1155 x_{3}+4 x_{1} x_{2}+602 x_{1} x_{3}+222 x_{2} x_{3}
$$

In this case, the porosity of the vibro-compacted mixture was described by the following regression equation:

$$
V_{s p}=37.8 x_{1}+32.3 x_{2}+27 x_{3}-7.8 x_{1} x_{2}-52 x_{1} x_{3}-6.6 x_{2} x_{3}
$$

The resulting equations are graphically presented in Figures 4-6, from which it can be seen that:

- The nature of the change in the bulk density of the mixture in its natural and vibrocompacted state is the same;

- In the vibro-compacted state, the maximum bulk density can reach $1272 \mathrm{~kg} / \mathrm{m}^{3}$ and can reach $1115 \mathrm{~kg} / \mathrm{m}^{3}$ in the natural state;

- The maximum density and maximum porosity are achieved with discontinuous granulometry (no grains with a fraction of $2.5-5 \mathrm{~mm}$ );

- When the relative content of coarse aggregates $(5-10 \mathrm{~mm})$ in the mixture is more than $40 \%$, the voidness and bulk density of the mixture is influenced by the fraction of $1.25-2.5 \mathrm{~mm}$;

- With a relative content of a mixture of coarse aggregate (5-10 $\mathrm{mm}$ ) less than $40 \%$, fluctuations in the number of fine fractions have practically no effect on the voidness and bulk density. 


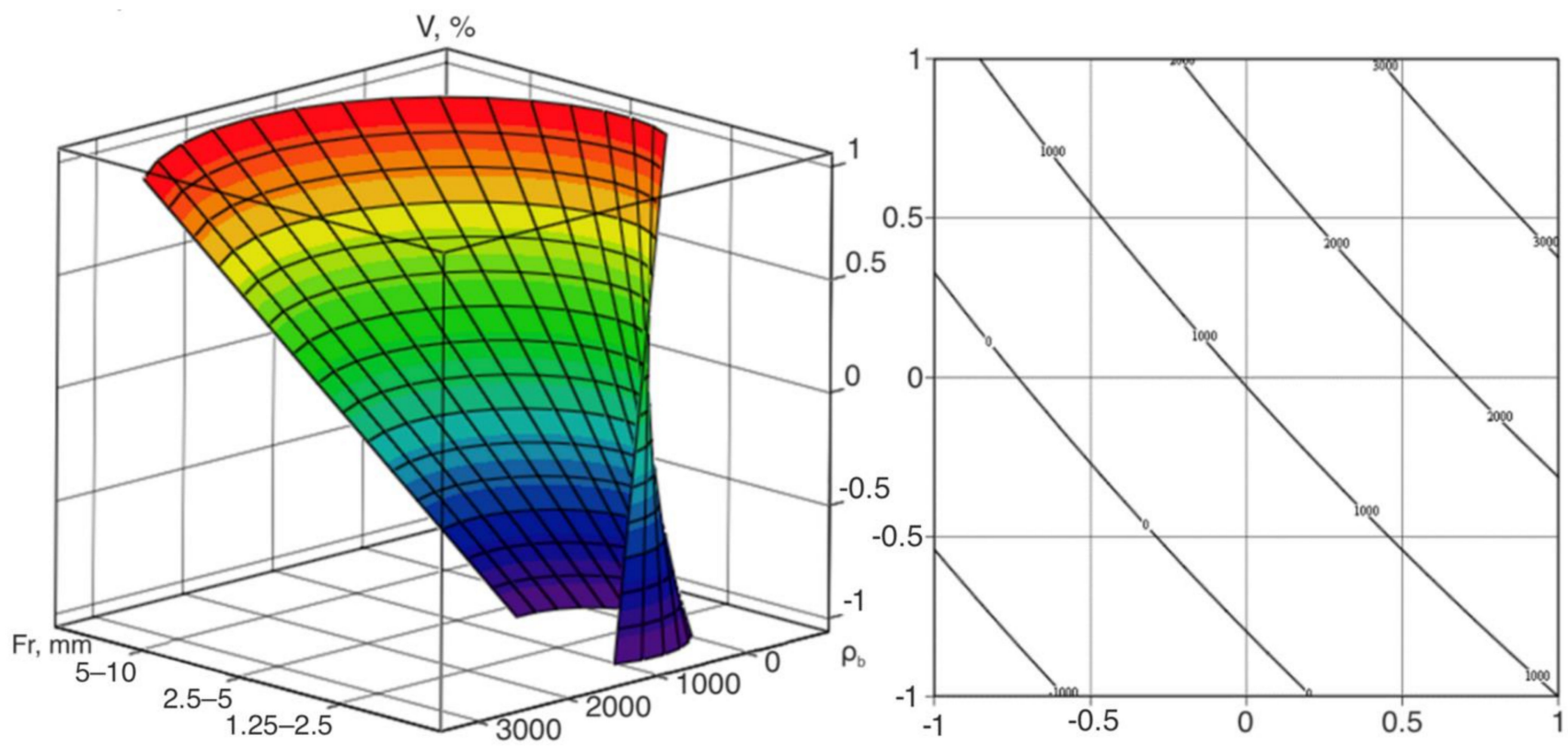

Figure 4. Dependence of the bulk density of a slag pumice mixture depending on the volumetric content of various types of fractions.
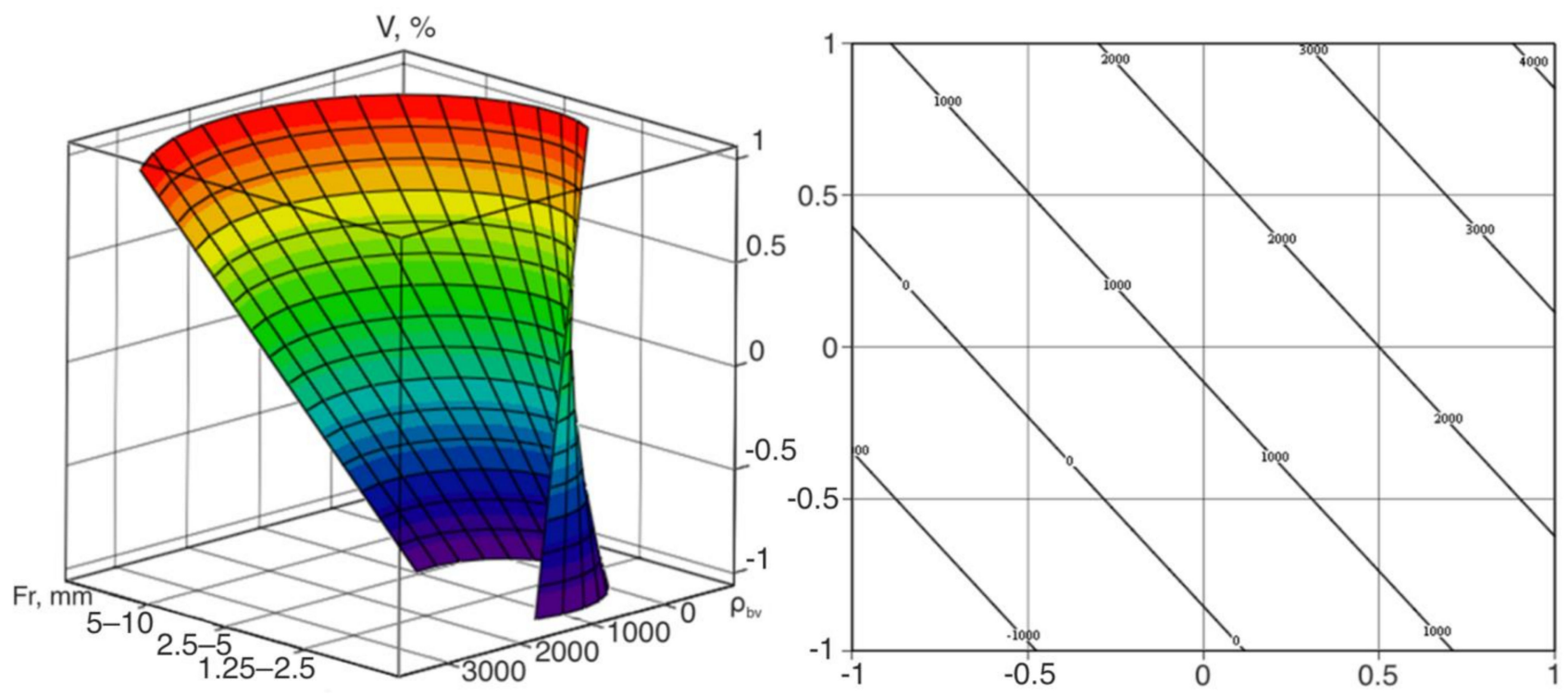

Figure 5. Dependence of the bulk density of a vibro-compacted mixture of slag pumice on the volumetric content of various types of fractions.

The influence of the porous aggregate on the physical and mechanical properties of compacted concrete in which porous material replaced part of the dense fractions was established by control tests using specimens for axial compression, axial tension, and bending tension. The replacement of the concrete components was conducted at a constant cement consumption rate without changing the total volume of the aggregate mixture. 

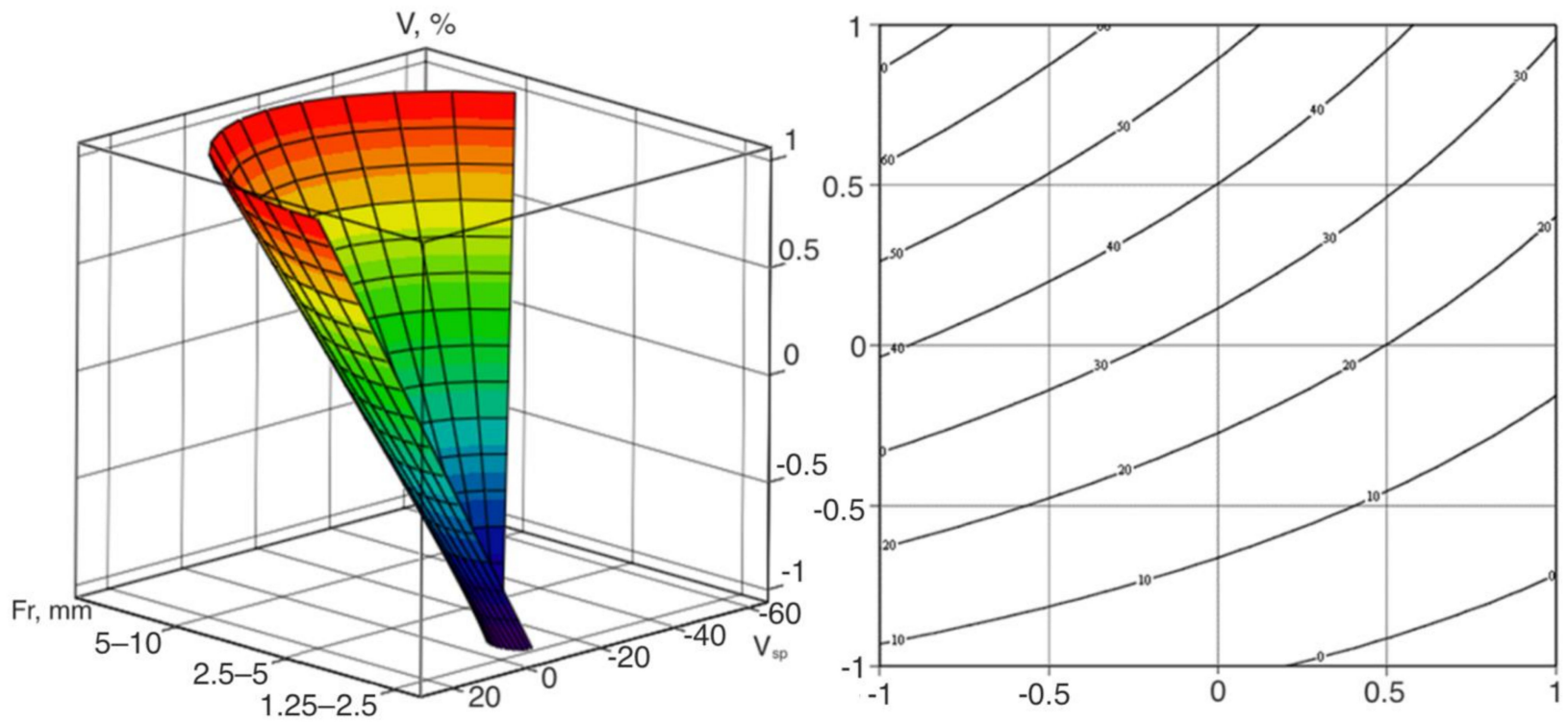

Figure 6. Dependence of the voidness of a slag pumice mixture on the volumetric content of various types of fractions.

In the studied compositions, up to $50 \%$ of the volume of dense aggregate was replaced with the same volume of the porous one.

To identify the most effective grain compositions of the combined aggregates, the combinations shown in Table 9 were investigated. The test results of the concretes made with the indicated grain compositions are presented in Table 9 and Figure 7.

CCQ characterizes the possibility of reducing the weight of buildings while maintaining or even improving the basic properties of materials. The structural quality factor is defined as the ratio of the compressive strength to the relative density $\mathrm{MPa} \times \mathrm{m}^{3} / \mathrm{kg}$ :

$$
\mathrm{CCQ}=\frac{R_{b . c u b}}{\rho_{C M}}
$$

where $R_{b . c u b}$ is compressive strength, $\mathrm{MPa}$;

$\rho_{c m}$ is the density of the concrete mixture, $\mathrm{kg} / \mathrm{m}^{3}$.

SC-designation of the concrete control composition (without slag pumice); S1-S5designation of the compositions (with different contents of slag pumice).

Table 9. Test results of concrete with different contents of porous aggregate.

\begin{tabular}{|c|c|c|c|c|c|c|c|}
\hline \multirow{3}{*}{$\begin{array}{l}\text { Composition } \\
\text { Code }\end{array}$} & \multirow{3}{*}{$\begin{array}{c}\text { Quartz Sand, } \\
\%\end{array}$} & \multirow{3}{*}{$\begin{array}{c}\text { Granite Crushed } \\
\text { Stone, } \%\end{array}$} & \multirow{2}{*}{\multicolumn{2}{|c|}{$\begin{array}{c}\text { Slag Pumice, \% } \\
\text { Fraction, mm }\end{array}$}} & \multirow{3}{*}{$\begin{array}{l}\text { Density, } \\
\mathrm{kg} / \mathrm{m}^{3}\end{array}$} & \multirow{3}{*}{$\begin{array}{c}\text { Compressive } \\
\text { Strength, } \\
\mathrm{MPa}\end{array}$} & \multirow{3}{*}{$\begin{array}{c}\mathrm{CCQ}, \mathrm{MPa} \times \\
\mathrm{m}^{3} / \mathrm{kg}\end{array}$} \\
\hline & & & & & & & \\
\hline & & & $5-10$ & $1.25-2.5$ & & & \\
\hline $\begin{array}{l}\text { cube concrete } \\
\text { test specimen } \\
\text { (SC) }\end{array}$ & 100 & 100 & 0 & 0 & 2455 & 65.2 & $26.6 \times 10^{-3}$ \\
\hline $\mathrm{S} 1$ & 90 & 90 & 10 & 10 & 2313 & 62.9 & $27.2 \times 10^{-3}$ \\
\hline S2 & 80 & 80 & 20 & 20 & 2175 & 60.8 & $28.0 \times 10^{-3}$ \\
\hline S3 & 70 & 70 & 30 & 30 & 2035 & 59.5 & $29.2 \times 10^{-3}$ \\
\hline S4 & 60 & 60 & 40 & 40 & 1880 & 59.1 & $31.4 \times 10^{-3}$ \\
\hline S5 & 50 & 50 & 50 & 50 & 1805 & 52.7 & $29.2 \times 10^{-3}$ \\
\hline
\end{tabular}




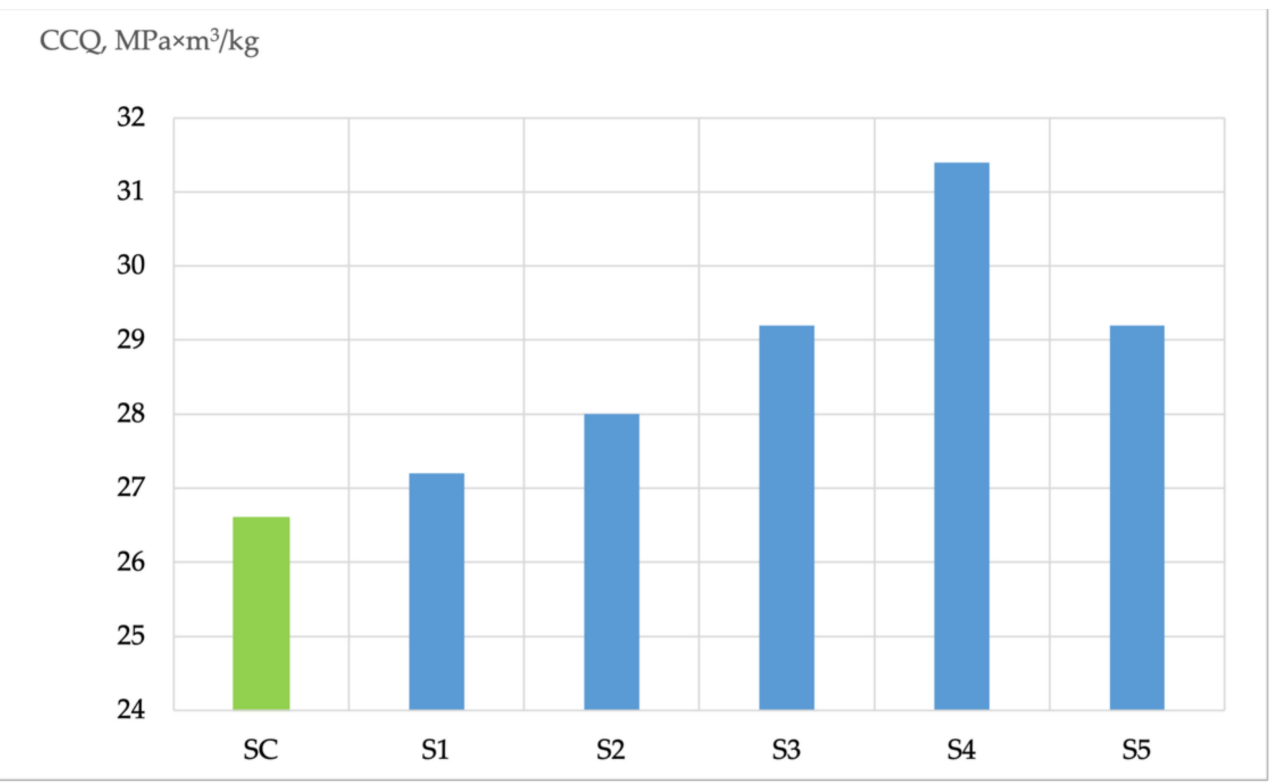

Figure 7. Diagram of CCQ for the volume ratio of porous and dense aggregates. SC - the control composition of concrete (without slag pumice); S1-S5—compositions by Table 9.

Analysis of the obtained results and their comparison with the results obtained by other authors $[2,8,20,21,33,34]$ indicates that the inclusion of slag pumice in the composition of concrete instead of as part of the dense aggregates leads to an increase in the CCQ, that is, a decrease in the compressive strength of the concrete is compensated by an even more significant decrease in the density of the material, which means a decrease in mass. The maximum increase of CCQ on the combined aggregate is observed when part of the coarse and small dense aggregate is replaced with slag pumice at $40 \%$ of the total volume of these aggregates in the concrete mixture.

Further, this research was conducted to study the strength and deformation characteristics of LFRC on a combined aggregate. Based on preliminary studies, the optimal composition of concrete on a combined aggregate (S4) was determined, which was subsequently used to manufacture LFRC prototypes on a combined aggregate.

The dependence of the change in the strength and deformation characteristics of lightweight fiber concretes on a combined aggregate was studied by changing the volume content of the fiber in the composition of the concrete mixture and the technological methods of its distribution.

As a result of testing the control samples (S4), the strength characteristics of the original concrete were established: $R_{b . c u b}=59.1 \mathrm{MPa}, R_{b}=23.6 \mathrm{MPa} ; R_{b t}=5.9 \mathrm{MPa} ; R_{b t b}=4.1 \mathrm{MPa}$; $\varepsilon_{b R}=1.87 \mathrm{~mm} / \mathrm{m} \times 10^{-3} ; \varepsilon_{b t b R}=1.24 \mathrm{~mm} / \mathrm{m} \times 10^{-4} ; E_{b}=E_{b t b}=35.3 \mathrm{MPa} \times 10^{3}$.

The determination of the strength characteristics of LFRC on a combined aggregate was conducted using regression dependencies, the type, and the values of the coefficients that were determined by the mathematical planning methods of the experiment.

As functions, the strength and deformation characteristics of LFRC on a combined aggregate vary depending on the volumetric content of the fiber in the composition of the concrete mixture and its distribution method during the preparation of the concrete fiber-reinforced concrete mixture are taken.

The following parameters were taken as the response function:

- $\quad R_{\text {b.cub }}(\mu, \mathrm{t})$-cube compressive strength, MPa;

- $\quad R_{b}(\mu, \mathrm{t})$ - prismatic compressive strength, $\mathrm{MPa}$;

- $\quad R_{b t}(\mu, \mathrm{t})$-bending tensile strength, MPa;

- $\quad R_{b t b}(\mu, \mathrm{t})$-axial tensile strength, $\mathrm{MPa}$;

- $\varepsilon_{b R}(\mu, \mathrm{t})$-ultimate deformations during axial compression, $\mathrm{mm} / \mathrm{m} \times 10^{-3}$;

- $\varepsilon_{b t b R}(\mu, \mathrm{t})$-ultimate deformations during axial tension, $\mathrm{mm} / \mathrm{m} \times 10^{-4}$; 
- $\quad E_{b}=E_{b t b}(\mu, \mathrm{t})$ - elastic modulus, $\mathrm{MPa} \times 10^{3}$.

As variables, the volumetric content of the fiber was taken. The method of its distribution in the preparation of the fiber-concrete mixture in absolute terms with different levels of variation and the values of the various factors are presented in Table 10.

Table 10. Values of the variation factors of the FFE $2 k$.

\begin{tabular}{|c|c|c|c|c|c|c|}
\hline \multirow{2}{*}{$\mathbf{N}$} & \multirow{2}{*}{ Factor Code } & \multirow{2}{*}{$\begin{array}{c}\text { The Physical Meaning of } \\
\text { the Factor }\end{array}$} & \multirow{2}{*}{$\begin{array}{c}\text { Unit } \\
\text { Measurements }\end{array}$} & \multicolumn{3}{|c|}{ Factor Levels } \\
\hline & & & & -1 & 0 & +1 \\
\hline 1 & $\mu$ & $\begin{array}{l}\text { Volumetric content of } \\
\text { fibers }(\mu), \%\end{array}$ & $\%$ & 1.5 & 2 & 2.5 \\
\hline 2 & $\mathrm{t}$ & Fiber distribution method & - & $1 \mathrm{t}$ & $2 t$ & $3 t$ \\
\hline
\end{tabular}

$1 \mathrm{t}-$ premixing of cement, water + mixing with fiber + mixing with sand and gravel. $2 \mathrm{t}-$ premixing of cement, sand, crushed stone + mixing with fiber + mixing with water. $3 \mathrm{t}$ - premixing of cement, sand, gravel, water + mixing with fiber.

The results of experimental studies on the effect of the volumetric content of fiberreinforced concrete and the method of its distribution in the preparation of a fiber-concrete mixture on the strength and deformation characteristics of LFRC on a combined aggregate are presented in Table 11 and Figures 8-12.

Table 11. Results of experimental studies on the influence of the volumetric content of fiber-reinforced concrete and the method of its distribution in the preparation of a fiber-concrete mixture on the physical-mechanical and deformative characteristics of LFRC on a combined aggregate.

\begin{tabular}{|c|c|c|c|c|c|c|c|c|c|c|c|}
\hline $\mathbf{N}$ & $\begin{array}{c}\text { Volumetric } \\
\text { Content of } \\
\text { Fibers, \% }\end{array}$ & $\begin{array}{l}\text { Fiber Dis- } \\
\text { tribution } \\
\text { Method }\end{array}$ & $\rho, \mathrm{kg} / \mathrm{m}^{3}$ & $\begin{array}{c}\mathbf{R}_{\text {b.cub }} \\
\mathrm{MPa}\end{array}$ & $\begin{array}{c}\mathrm{CCQ}, \mathrm{MPa} / \mathrm{kg} \\
\times \mathrm{m}^{3} \\
\left(\times 10^{-3}\right)\end{array}$ & $\mathrm{R}_{\mathrm{b}}, \mathrm{MPa}$ & $\mathbf{R}_{\mathrm{bt}}, \mathbf{M P a}$ & $\mathrm{R}_{\mathrm{btb}}, \mathrm{MPa}$ & $\begin{array}{c}\mathcal{E}_{\mathrm{bR}} \\
\mathrm{mm} / \mathrm{m}\end{array} \times$ & $\begin{array}{c}\mathcal{E}_{\mathrm{btbR}} \\
\mathrm{mm} / \mathrm{m}\end{array} \underset{10^{-4}}{ } \times$ & $\begin{array}{c}\mathrm{E}_{\mathrm{b}}=\mathrm{E}_{\mathrm{btb}}, \\
\mathrm{MPa} \times \\
10^{3}\end{array}$ \\
\hline 1 & 1.5 & $1 \mathrm{t}$ & 1886 & 56.7 & 30.1 & 25.4 & 6.8 & 3.91 & 1.86 & 1.23 & 35.6 \\
\hline 2 & 2.5 & $1 \mathrm{t}$ & 1889 & 58.9 & 31.2 & 26.7 & 7.1 & 4.12 & 1.73 & 1.14 & 38.2 \\
\hline 3 & 1.5 & $3 t$ & 1886 & 57.9 & 30.7 & 24.3 & 6.9 & 4.05 & 1.88 & 1.24 & 35.1 \\
\hline 4 & 2.5 & $3 t$ & 1889 & 59.5 & 31.5 & 27.1 & 7.1 & 4.17 & 1.81 & 1.20 & 36.5 \\
\hline 5 & 1.5 & $2 t$ & 1886 & 62.6 & 33.2 & 27.9 & 7.5 & 4.38 & 1.79 & 1.18 & 36.9 \\
\hline 6 & 2.5 & $2 t$ & 1889 & 64.9 & 34.4 & 28.3 & 7.8 & 4.54 & 1.78 & 1.17 & 37.2 \\
\hline 7 & 2 & $1 \mathrm{t}$ & 1888 & 57.5 & 30.5 & 26.1 & 6.9 & 4.03 & 1.85 & 1.22 & 35.8 \\
\hline 8 & 2 & $3 t$ & 1888 & 58.3 & 30.9 & 25.8 & 7.0 & 4.08 & 1.82 & 1.20 & 36.4 \\
\hline 9 & 2 & $2 t$ & 1888 & 66.6 & 35.3 & 29.6 & 7.9 & 4.56 & 1.70 & 1.11 & 39.3 \\
\hline
\end{tabular}

$\mathrm{R}, \mathrm{MPa}$

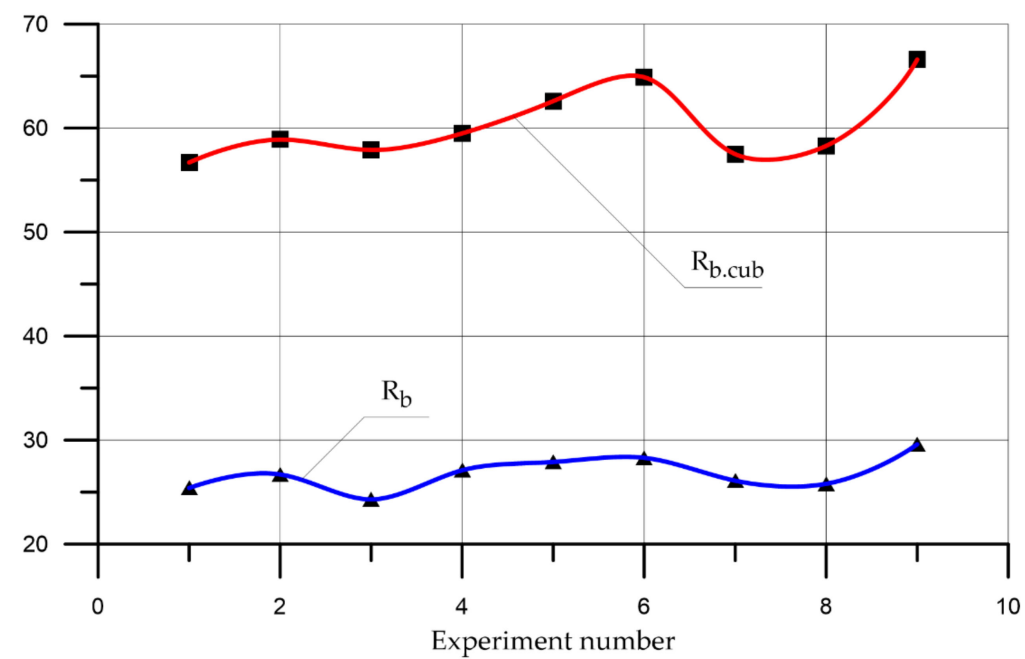

Figure 8. Change in the compressive strength and the prismatic LFRC on a combined aggregate depending on the volumetric content of fiber-reinforced concrete and the method of its distribution during the preparation of a fiber-reinforced concrete mixture. 
$\mathrm{R}, \mathrm{MPa}$

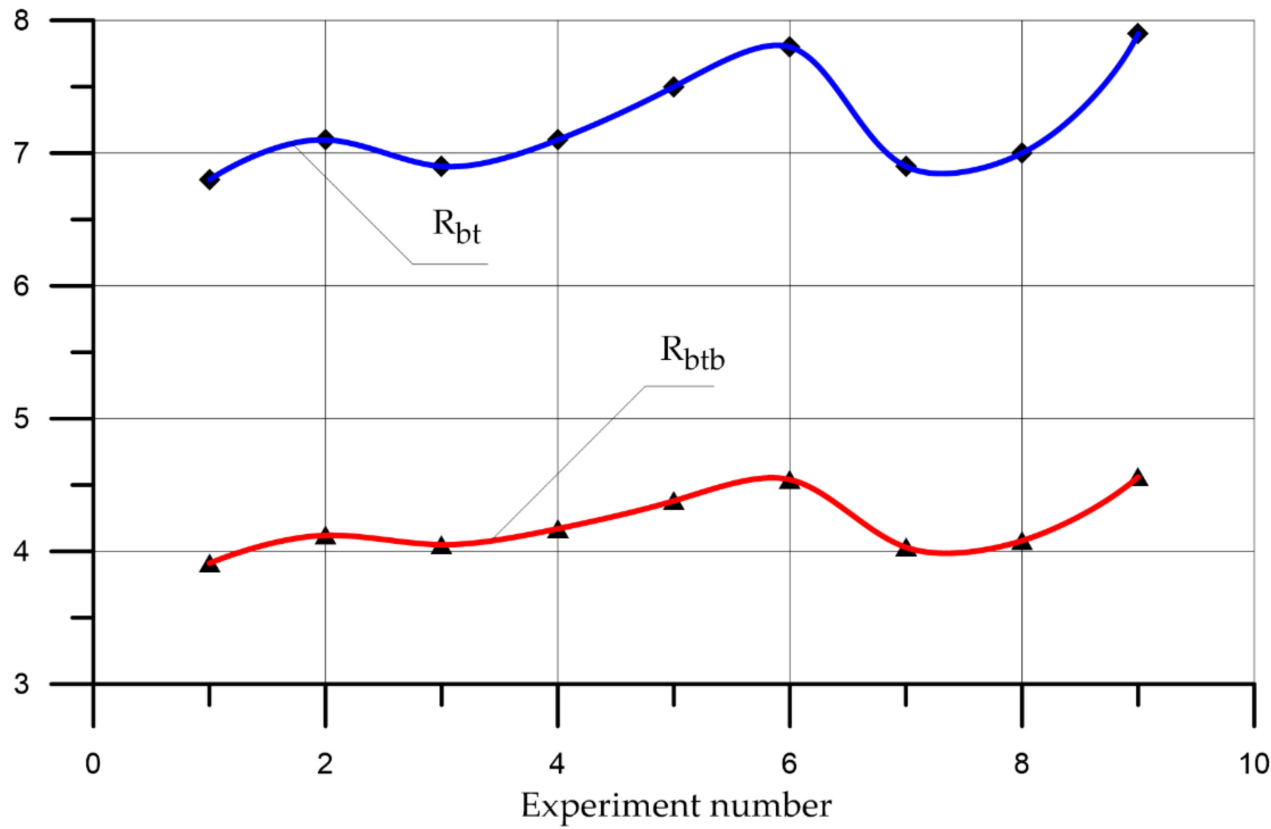

Figure 9. Change in the tensile strength in the bending and axial tension of LFRC on a combined aggregate depending on the volumetric content of fiber-reinforced concrete and the method of its distribution in the preparation of a fiber-reinforced concrete mixture.

$\varepsilon_{\mathrm{bR}}, \mathrm{mm} / \mathrm{m} \times 10^{-3}$

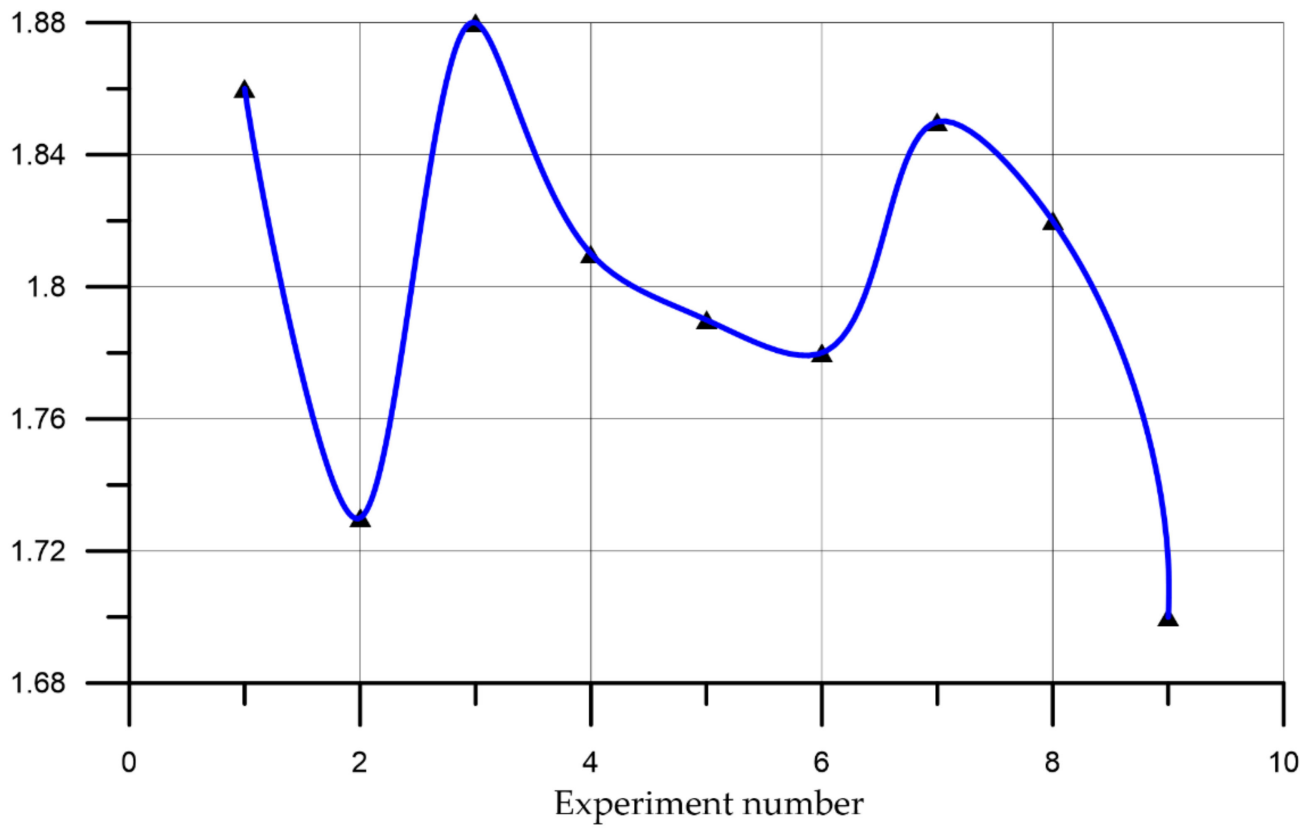

Figure 10. Change in the ultimate deformations during the axial compression of LFRC on a combined aggregate, depending on the volumetric content of fiber-reinforced concrete and the method of its distribution during the preparation of a fiber-reinforced concrete mixture. 
$\varepsilon_{\text {btbR }}, \mathrm{mm} / \mathrm{m} \times 10^{-4}$

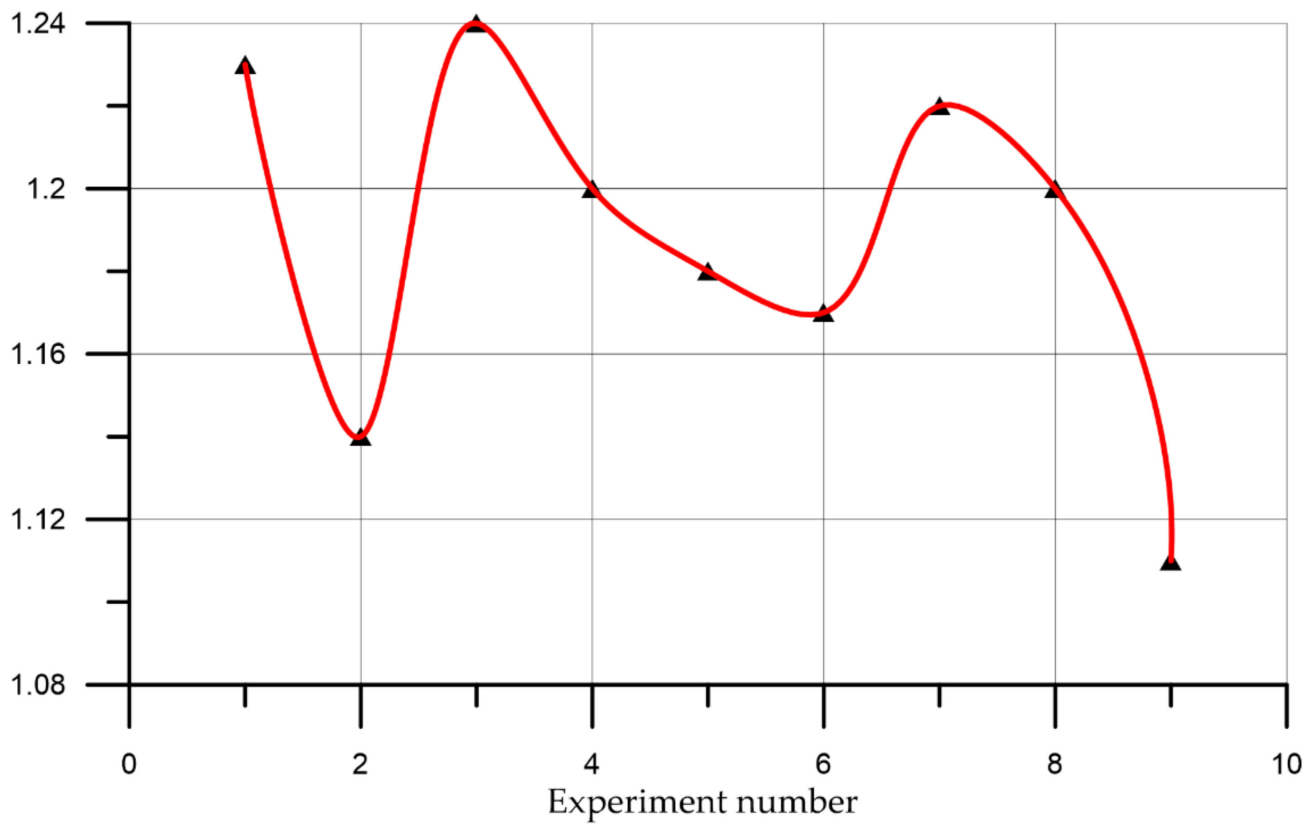

Figure 11. Changes in the ultimate deformations during the axial tension of LFRC on a combined aggregate, depending on the volumetric content of fiber-reinforced concrete and the method of its distribution when preparing a fiber-reinforced concrete mixture.

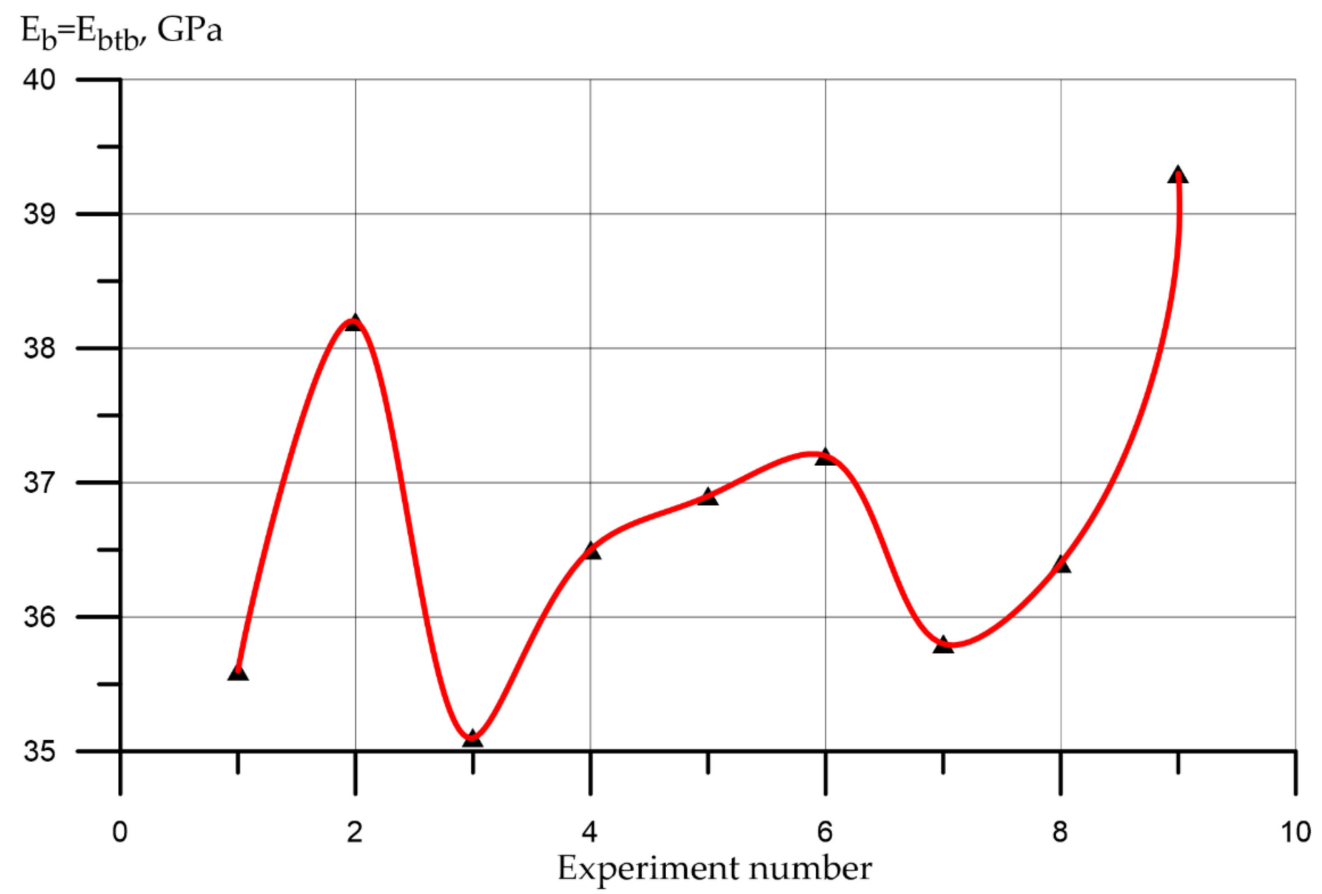

Figure 12. Change in the modulus of elasticity of LFRC on a combined aggregate depending on the volumetric content of fiber-reinforced concrete and the method of its distribution during the preparation of a fiber-reinforced concrete mixture.

Figures 8-12 show that the largest increase in compressive and tensile strength in bending, prismatic strength, axial tensile strength, elastic modulus as well as the smallest ultimate deformations during the axial compression and tension of fiber-reinforced concrete are observed with the following composition and technological parameters: the volumetric content of basalt fiber is $2 \%$, the method of fiber distribution is $2 t$ (preliminary mixing of 
cement, sand, crushed stone + mixing with fiber + mixing with water). This amount of basalt fiber is also confirmed by previous studies [35] and is comparable to the results of similar studies by other authors $[2,5,11]$. This effective way of distributing the fibers is logical since at first, it is advisable to thoroughly mix the dry components of the concrete mixture and to then evenly distribute the prepared fiber in the resulting mixture and add the water into the ready-made dry fiber-concrete mixture. This method of preparing a fiber-reinforced concrete mixture allows the most uniform distribution of fiber throughout the entire volume of concrete and consequently, ready-made fiber-reinforced concrete with the best strength and deformation characteristics to be obtained, which is in good agreement with similar studies by other authors $[2,5,11]$.

Based on the results of studies using the least squares method, the basic regression equations were obtained, which are presented in the form of polynomials of the 2nd degree:

$$
\begin{gathered}
R_{b . c u b}(\mu, t)=60.32+0.113 \mu+0.0482 t-0.15 \mu t-0.7257 \mu^{2}-6.5757 t^{2} \\
R_{b}(\mu, t)=26.8+0.0834 \mu-0.0185 t+0.375 \mu t-0.554 \mu^{2}-2.704 t^{2} \\
R_{b t}(\mu, t)=7.22+0.148 \mu+0.0037 t-0.025 \mu t-0.0677 \mu^{2}-0.7677 t^{2} \\
R_{b t b}(\mu, t)=4.2+0.0091 \mu+0.0044 t-0.0225 \mu t-0.029 \mu^{2}-0.434 t^{2} \\
\varepsilon_{b R}(\mu, t)=1.72-0.0067 \mu-0.0037 t+0.0025 \mu t+0.1064 \mu^{2}+0.0964 t^{2} \\
\varepsilon_{b t b R}(\mu, t)=0.97-0.0026 \mu-0.002 t+0.1064 \mu^{2}+0.1249 t^{2} \\
E_{b R}=E_{b t b R}(\mu, t)=36.78-0.0796 \mu-0.0296 t-0.3 \mu t-0.5888 \mu^{2}-1.5388 t^{2}
\end{gathered}
$$

Figures 13 and 14 show diagrams of compression " $\varepsilon_{\mathrm{b}}-\sigma_{\mathrm{b}}$ " and tension " $\varepsilon_{\mathrm{btb}}-\sigma_{\mathrm{btb}}$ " for the control composition concrete (S4) and for LFRC on a combined aggregate with the best strength and deformation characteristics.

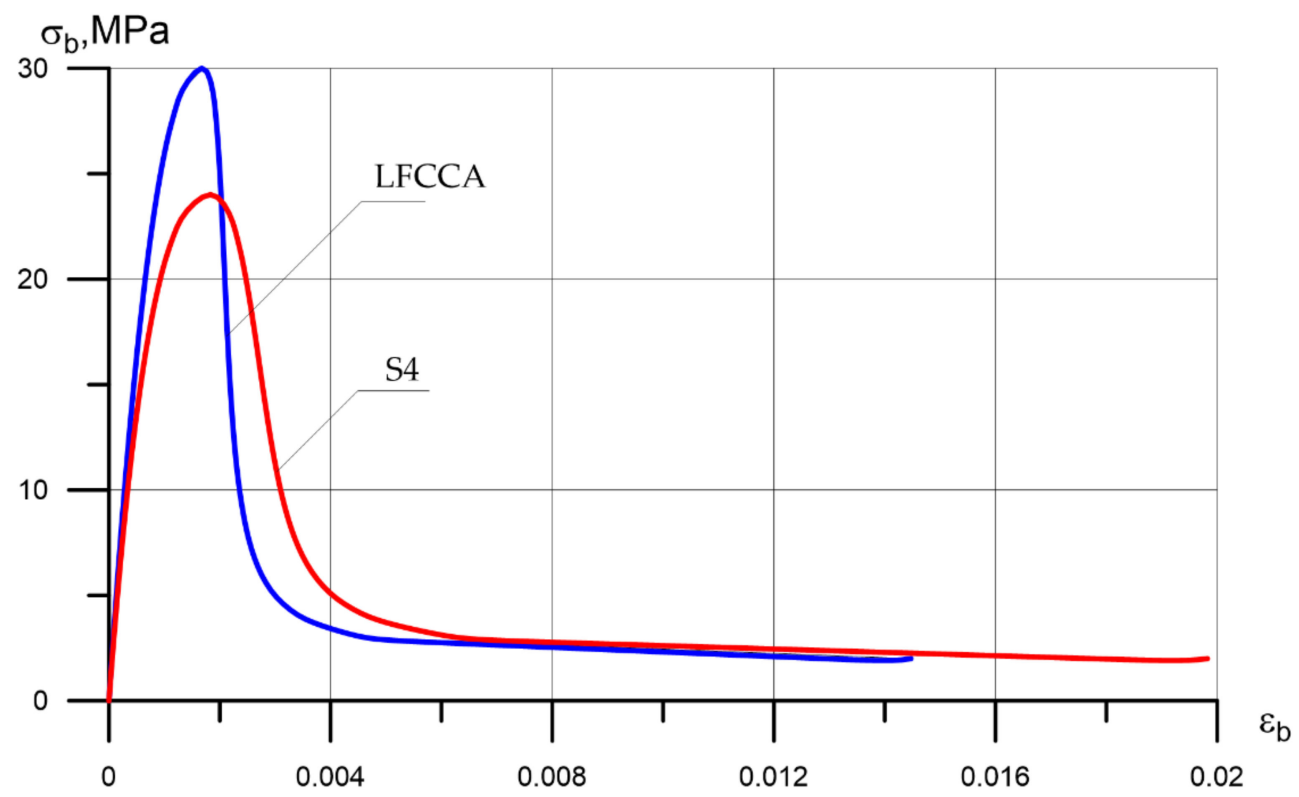

Figure 13. Diagram of the state of compressed concrete (S4-control composition; LFCCA—LFRC on a combined aggregate). 


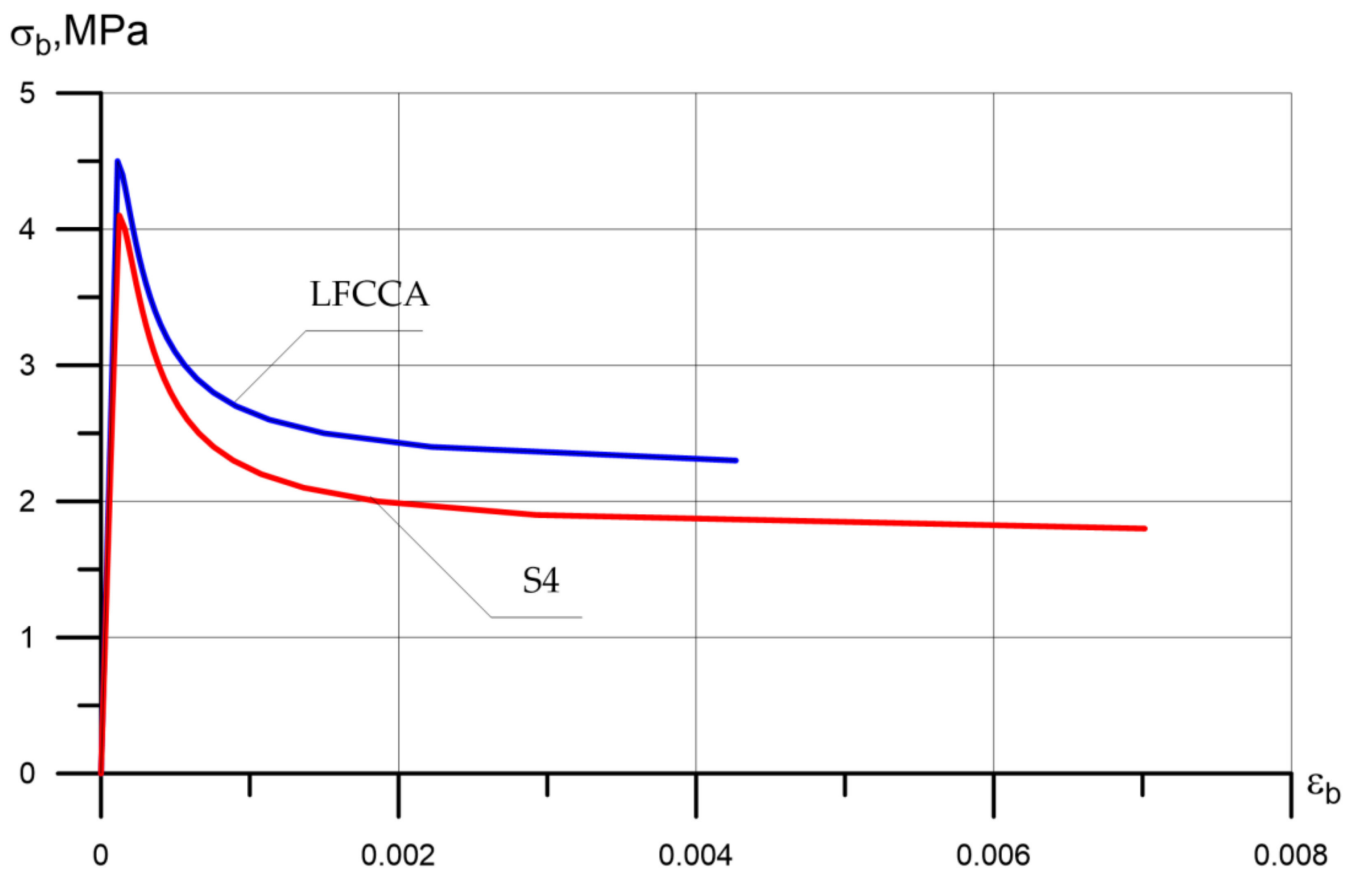

Figure 14. Diagram of the state of tensioned concrete (S4-control composition of concrete; LFCCALFRC on a combined aggregate).

\section{Discussion}

A comparison of the results was conducted with the data from the study of the mechanical and strength properties of the lightweight pumice concrete reinforced with basalt fiber (BPLC) containing nano-ground calcium carbonate (GCC) [2]. GCC was used as a standard substitute for Portland cement in the amounts of $5 \%, 10 \%, 15 \%, 20 \%$, and $25 \%-$, and $6-\mathrm{mm}$ long basalt fibers were added in two grades of $0.5 \%$ and $1 \%$ by volume. Experimental results showed that at an early age, the mixture with GCC had lower mechanical strength results; however, it was comparable in strength to the reference mixes at a later age. The addition of GCC also decreased water absorption, sorption capacity, and showed an increase in magnesium sulfate resistance compared to the reference lightweight concrete. The use of basalt fiber improved the mechanical properties of BPLC, but the inclusion of the fiber reduced the properties of the fresh concrete.

However, in [2], porous substitutes for coarse aggregate made of dense rocks, which create a frame and provide the bearing capacity of concrete, have not been studied.

The research work that [5] presents is an experimental study of the mechanical behavior of structural expanded clay concrete from basalt fiber. The main purpose of this study [5] was to check the effect of crushed basalt fiber in expanded clay concrete to increase its strength, that is, its absolute characteristics. However, [5] did not study the relative physical and mechanical characteristics, in particular, it did not determine the coefficient of constructive quality, that is, the most important characteristic for and lightweight concrete.

The aspects noted above are widely disclosed and highlighted by us in this study.

As a result of the analysis of Figures 13 and 14, the following was established: Based on the obtained deformation diagrams, the peak with displacement up and to the left of the diagram is presented in the deformation of LFRC on a combined aggregate. On the other hand, the remaining diagrams of the control concrete compositions had a lower peak with a shift to the right. Thus, based on the analysis of the data obtained on the deformation of the tested sample, it can be concluded that the recommended composition and technological methods for controlling the strength and deformative characteristics of LFRC on a combined aggregate are advisable.

According to the results of experimental studies on the influence of the volumetric content of fiberglass and the method of its distribution in the preparation of a fiber-reinforced 
concrete mixture on the strength and deformation characteristics of LFRC on a combined aggregate, the most effective combination of these factors was determined. AS such, with the inclusion of basalt fiber at $2 \%$ of the volume of the concrete mixture where the fiber distribution was conducted according to the $2 \mathrm{t}$ method (preliminary mixing of cement, sand, crushed stone + mixing with fiber + mixing with water), the best values of the strength and deformation characteristics of LFRC are observed in the combined filler. Thus, in comparison to the values obtained when testing the control samples, the increase in compressive strength was $12 \%$, the value of the prismatic strength increased by $25 \%$, the tensile bending strength increased by $34 \%$, and the axial tensile strength increased by $11 \%$. The ultimate deformations during axial compression decreased by $10 \%$, decreased by $12 \%$ during axial compression tests, and the modulus of elasticity increased by $11 \%$. Cement consumption remained unchanged.

CCQ of LFRC on a combined aggregate is $35.3 \times 10^{-3} \mathrm{MPa} \times \mathrm{m}^{3} / \mathrm{kg}$. This concrete is the most effective in terms of construction since in comparison to traditional heavy concrete, it has a sufficiently high strength at a lower density value. The coefficient of constructive quality of concrete on dense aggregate is $26.6 \times 10^{-3} \mathrm{MPa} \times \mathrm{m}^{3} / \mathrm{kg}$, and for the control composition concreate $\mathrm{S} 4$, it was $31.4 \times 10^{-3} \mathrm{MPa} \times \mathrm{m}^{3} / \mathrm{kg}$. Thus, selecting a rational grain size composition for the porous aggregate and its ratio with the dense aggregate made it possible to achieve a CCQ increase of more than $18 \%$ compared to the control composition on the dense aggregate. In turn, the recipe-technological methods for controlling the characteristics of LFRC on a combined aggregate proposed in this study led to an increase in the CCQ by more than $32 \%$ compared to the control composition on dense aggregate and by more than $13 \%$ compared to the control composition S4.

Thus, in comparison with the values obtained when testing the control samples, the increase in compressive strength was $12 \%$, the value of the prismatic strength increased by $25 \%$, the tensile bending strength increased by $34 \%$, and the axial tensile strength increased by $11 \%$. The ultimate deformations during axial compression decreased by $10 \%$ and by $12 \%$ with axial tension, and the elasticity modulus increased by $11 \%$. Cement consumption remained unchanged.

\section{Conclusions}

As a result of our research, we made the following conclusions: It has been established that using the technology of combining aggregates, namely replacing part of a dense, heavy, expensive granite aggregate that is of a similar volume but lower in density (by 20-30\%) and, consequently in cost, aggregate, for example, such as slag pumice, it is possible to achieve preservation and in some cases with certain rational combinations of technological and recipe parameters, an increase in structural and deformative characteristics, an improvement in the quality of concrete as a whole, and at the same time, a significant reduction in the weight of the structure due to a decrease in the mass and density of the concrete. This increases the coefficient of constructive quality of such concretes.

At the same time, in the study, rational combinations of technological and recipe parameters were determined, various combinations were investigated and were expressed as a percentage, representing the ratio between a dense aggregate and its porous analogue, which are combined in the concrete while having a positive effect on the general properties of the reinforced concrete structures made in such a way.

It was also found that fiber reinforcement with basalt fibers gives a synergistic effect together with the combination of aggregates that are both heavy and porous.

Thus, using a complex recipe solution that includes a combination of a combined aggregate and basalt fiber, we significantly reduce the weight of the structure, achieve resource and material savings, energy savings in the production and manufacturing of such products and structures as well as increase the strength characteristics, reduce the deformability, and achieve a positive effect in the construction of buildings and structures in general. 
Quantitative analysis can be assessed by the increase in such indicators as the coefficient of structural quality for the investigated type of concrete in comparison to control samples made from control compositions. Thus, the increase was up to $32 \%$.

Methodologically, the results obtained here can be substantiated as follows: Due to the use of lighter initial components-less dense aggregates-we achieved a smaller concrete mass, which is expressed as a sharp decrease in one of the main parameters. At the same time, by improving the recipe-technological processes and factors, we achieved an increase in strength, that is, an absolute increase in relation to the control composition. Thus, we justify the increase in the coefficient of constructive quality from the point of view of the methodology and that is expressed in the technological and recipe aspects and, ultimately, in the operational aspect.

Thus, it can be concluded that there is a significant effect resulting from a complex combination of aggregates and basalt fibers in concrete, thus obtaining a promising concrete: lightweight concrete on a combined aggregate with basalt fiber reinforcement.

Author Contributions: Conceptualization, L.R.M., S.A.S. and E.M.S.; methodology, L.R.M., A.N.B., S.A.S. and E.M.S.; software, S.A.S., E.M.S. and O.A.; validation, A.N.B., S.A.S. and E.M.S.; investigation, A.N.B., S.A.S. and E.M.S.; resources, B.M., O.A. and L.R.M.; data curation, A.N.B., S.A.S. and E.M.S.; writing—original draft preparation, A.N.B., S.A.S. and E.M.S.; writing-review and editing, A.N.B., S.A.S. and E.M.S.; visualization, O.A., S.A.S. and E.M.S.; supervision, B.M., O.A. and L.R.M.; project administration, L.R.M. and B.M.; funding acquisition, A.N.B., O.A. and B.M. All authors have read and agreed to the published version of the manuscript.

Funding: This research was funded by Don State Technical University, Rostov-on-Don, Russia.

Institutional Review Board Statement: The study does not include research on humans or animals. Informed Consent Statement: Not applicable.

Data Availability Statement: Data sharing not applicable.

Acknowledgments: The authors would like to acknowledge the administration of Don State Technical University for their resources and financial support.

Conflicts of Interest: The authors declare no conflict of interest. The funders had no role in the design of the study; in the collection, analyses, or interpretation of data; in the writing of the manuscript, or in the decision to publish the results.

\section{References}

1. Begich, Y.E.; Klyuev, S.V.; Jos, V.A.; Cherkashin, A.V. Fine-grained concrete with various types of fibers. Mag. Civ. Eng. 2020, 97, 9702. [CrossRef]

2. Karaburc, S.N.; Yildizel, S.A.; Calis, G.C. Evaluation of the basalt fiber reinforced pumice lightweight concrete. Mag. Civ. Eng. 2020, 94, 81-92. [CrossRef]

3. Anysz, H.; Narloch, P. Designing the composition of cement stabilized rammed earth using artificial neural networks. Materials 2019, 12, 1396. [CrossRef] [PubMed]

4. Narloch, P.; Hassanat, A.; Tarawneh, A.S.; Anysz, H.; Kotowski, J.; Almohammadi, K. Predicting compressive strength of cement-stabilized rammed earth based on SEM images using computer vision and deep learning. Appl. Sci. $2019,9,5131$. [CrossRef]

5. Galishnikova, V.V.; Kharun, M.; Koroteev, D.D.; Chiadighikaobi, P.C. Basalt fiber reinforced expanded clay concrete for building structures. Mag. Civ. Eng. 2021, 101, 10107. [CrossRef]

6. Al Zand, A.W.; Hosseinpour, E.; Badaruzzaman, W.H.W.; Ali, M.M.; Yaseen, Z.M.; Hanoon, A.N. Performance of the novel C-purlin tubular beams filled with recycled-lightweight concrete strengthened with CFRP sheet. J. Build. Eng. 2021, $43,102532$. [CrossRef]

7. Marais, H.; Christen, H.; Cho, S.; De Villiers, W.; Van Zijl, G. Computational assessment of thermal performance of 3D printed concrete wall structures with cavities. J. Build. Eng. 2021, 41, 102431. [CrossRef]

8. Ferrotto, M.F.; Fischer, O.; Cavaleri, L. Analysis-oriented stress-strain model of CRFP-confined circular concrete columns with applied preload. Mater. Struct. 2018, 51, 44. [CrossRef]

9. Beskopylny, A.; Kadomtseva, E.; Strelnikov, G.; Morgun, L.; Berdnik, Y.; Morgun, V. Model of heterogeneous reinforced fiber foam concrete in bending. IOP Conf. Ser. Mater. Sci. Eng. 2018, 365, 032023. [CrossRef]

10. Do, T.M.D.; Lam, T.Q.K. Design parameters of steel fiber concrete beams. Mag. Civ. Eng. 2021, 102, 10207. [CrossRef] 
11. Kang, I.-K.; Kim, S.-H. Compressive strength testing of hybrid concrete-filled fiber-reinforced plastic tubes confined by filament winding. Appl. Sci. 2021, 11, 2900. [CrossRef]

12. Abd Elrahman, M.; Sikora, P.; Chung, S.Y.; Stephan, D. The performance of ultra-lightweight foamed concrete incorporating nanosilica. Archiv. Civ. Mech. Eng. 2021, 21, 79. [CrossRef]

13. Huynh, T.-P.; Pham, V.-H.; Do, N.-D.; Nguyen, T.-C.; Ho, N.-T. Performance evaluation of pre-foamed ultra-lightweight composites incorporating various proportions of slag. Period. Polytech. Civ. Eng. 2021, 65, 76-286. [CrossRef]

14. Beskopylny, A.; Lyapin, A.; Anysz, H.; Meskhi, B.; Veremeenko, A.; Mozgovoy, A. Artificial neural networks in classification of steel grades based on non-destructive tests. Materials 2020, 13, 2445. [CrossRef] [PubMed]

15. Kulkarni, P.; Londhe, S.N.; Dixit, P.R. A comparative study of concrete strength prediction using artificial neural network multigene programming and model tree. Chall. J. Concr. Res. Lett. 2019, 5, 42-61. [CrossRef]

16. Kulkarni, P.; Londhe, S.N. Concrete strength prediction using artificial neural network and genetic programming. Chall. J. Concr. Res. Lett. 2018, 9, 75-84. [CrossRef]

17. Han, I.-J.; Yuan, T.-F.; Lee, J.-Y.; Yoon, Y.-S.; Kim, J.-H. Learned prediction of compressive strength of GGBFS concrete using hybrid artificial neural network models. Materials 2019, 12, 3708. [CrossRef] [PubMed]

18. Nikolyukin, A.N.; Yartsev, V.P.; Bondarev, B.A.; Korneeva, A.O. Modeling the adhesion of reinforcement in concrete based on an artificial neural network. Russ. J. Build. Constr. Archit. 2019, 2019. 2, 11-20. [CrossRef]

19. Haddad, R.; Haddad, M. Predicting fiber-reinforced polymer-concrete bond strength using artificial neural networks: A comparative analysis study. Struct. Concr. 2020, 22, 38-49. [CrossRef]

20. Bae, B.-I.; Lee, M.-S.; Choi, C.-S.; Jung, H.-S.; Choi, H.-K. Evaluation of the ultimate strength of the ultra-high-performance fiber-reinforced concrete beams. Appl. Sci. 2021, 11, 2951. [CrossRef]

21. Alani, A.H.; Bunnori, N.M.; Noaman, A.T.; Majid, T.A. Durability performance of a novel ultra-high-performance PET green concrete (UHPPGC). Constr. Build. Mater. 2019, 209, 395-405. [CrossRef]

22. Geiker, M.R.; Michel, A.; Stang, H.; Lepech, M.D. Limit states for sustainable reinforced concrete structures. Cem. Concr. Res. 2019, 122, 189-195. [CrossRef]

23. Belyaev, A.V.; Nesvetaev, G.V.; Mailyan, D.R. Design features of three-layer slab reinforced concrete structures. Mater. Sci. Forum 2018, 931, 264-268. [CrossRef]

24. Shilov, A.; Polskoy, P.; Mailyan, D.; Shilov, P. Initial crack effect on the strength of oblique cross sections of reinforced concrete beams strengthened with carbon fiber. E3S Web Conf. 2019, 110, 01053. [CrossRef]

25. Polskoy, P.P.; Mailyan, D.R.; Shilov, A.A. The cut span effect on the beams inclined sections strength reinforced with external composite reinforcement. Mater. Sci. Forum 2020, 974, 633-637. [CrossRef]

26. Shcherban', E.; Prokopov, A.Y.; Stel'Makh, S.; Shuyskiy, A.I. Effect of disperse reinforcement on the structural quality factor of vibrated and centrifuged concretes on the combined aggregate. Mater. Sci. Forum 2019, 974, 283-287. [CrossRef]

27. Stelmakh, S.A.; Shuyskiy, A.I.; Shcherban, E.M.; Prokopov, A.Y. Efficiency comparison of fiber reinforcement in vibrated and centrifuged concretes at different types of the applied heavy aggregate. MSF 2019, 974, 288-292. [CrossRef]

28. Mailyan, L.R.; Stel'makh, S.A.; Shcherban', E.M.; Khalyushev, A.K.; Smolyanichenko, A.S.; Sysoev, A.K.; Parinov, I.A.; Cherpakov, A.V. Investigation of integral and differential characteristics of variatropic structure heavy concretes by ultrasonic methods. Appl. Sci. 2021, 11, 3591. [CrossRef]

29. Stel'makh, S.A.; Shcherban', E.M.; Shuiskii, A.I.; Prokopov, A.Y.; Madatyan, S.M.; Parinov, I.A.; Cherpakov, A.V. Effects of the geometric parameters of mixer on the mixing process of foam concrete mixture and its energy efficiency. Appl. Sci. 2020, 10, 8055. [CrossRef]

30. GOST 10180 Concretes. Methods for Strength Determination Using Reference Specimens. Available online: http:/ / docs.cntd.ru/ document/1200100908 (accessed on 7 August 2021).

31. GOST 24452 Concretes. Methods of Prismatic, Compressive Strength, Modulus of Elasticity and Poisson's Ratio Determination. Available online: https:// docs.cntd.ru/document/9056198 (accessed on 7 August 2021).

32. GOST 27006 Concretes. Rules for Mix Proposing. Available online: https:/ / docs.cntd.ru/document/1200165762 (accessed on 7 August 2021).

33. Hameed, M.A.S.; Maula, B.H.; Bahnam, Q.M. An empirical relationship between compressive strength and ultrasonic pulse velocity for concrete. Int. Rev. Civ. Eng. 2019, 10. [CrossRef]

34. Kim, J.-J.; Yoo, D.-Y. Effects of fiber shape and distance on the pullout behavior of steel fibers embedded in ultra-high-performance concrete. Cem. Concr. Compos. 2019, 103, 213-223. [CrossRef]

35. Mailyan, L.R.; Beskopylny, A.N.; Meskhi, B.; Shilov, A.V.; Stel'makh, S.A.; Shcherban', E.M.; Smolyanichenko, A.S.; El'shaeva, D. Improving the structural characteristics of heavy concrete by combined disperse reinforcement. Appl. Sci. 2021, $11,6031$. [CrossRef] 